\title{
The Role of UAS-GIS in Digital Era Governance. A Systematic Literature Review
}

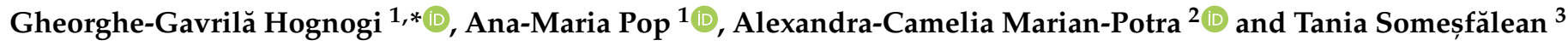 \\ 1 Centre for Regional Geography, Faculty of Geography, Babeș-Bolyai University, \\ 400006 Cluj-Napoca, Romania; ana-maria.pop@ubbcluj.ro \\ 2 Department of Geography, Faculty of Biology, Chemistry and Geography, West University of Timişoara, \\ 300223 Timișoara, Romania; alexandra.potra@e-uvt.ro \\ 3 Faculty of Geography, Babeș-Bolyai University, 400006 Cluj-Napoca, Romania; \\ tania.somesfalean@stud.ubbcluj.ro \\ * Correspondence: gheorghe.hognogi@ubbcluj.ro
}

Citation: Hognogi, G.-G.; Pop, A.-M.; Marian-Potra, A.-C.; Someșfălean, T. The Role of UAS-GIS in Digital Era Governance. A Systematic Literature Review. Sustainability 2021, 13, 11097. https://doi.org/10.3390/su131911097

Academic Editor: Pablo

Rodríguez-Gonzálvez

Received: 10 August 2021

Accepted: 26 September 2021

Published: 8 October 2021

Publisher's Note: MDPI stays neutral with regard to jurisdictional claims in published maps and institutional affiliations.

Copyright: (c) 2021 by the authors. Licensee MDPI, Basel, Switzerland. This article is an open access article distributed under the terms and conditions of the Creative Commons Attribution (CC BY) license (https:// creativecommons.org/licenses/by/ $4.0 /)$
Abstract: UAS (Unmanned Aircraft Systems) technologies, also known as UAV (Unmanned Aerial Vehicle), drones, or Remotely Piloted Aircraft System (RPAS) and GIS (Geographic Information System) are recognised for the value of the results that can be achieved by their combined use. However, their use and the results achieved are rarely framed within the context of Digital Era Governance (DEG), an undertaking that would significantly reduce the capabilities of knowledge transfer from the academic and/or private environment to the public domain. The purpose of this study was to highlight, by a bibliometric analysis, the areas of proposed use of this team of tools and the extent to which these can enter the sphere of interest of public administrations, especially local ones. From a methodological point of view, based on the 439 articles filtered from the Web of Science database where UAS/UAV and GIS technologies were used, several bibliometric analyses have emerged. VOSviewer and R (Bibliometrix tool) were used to conduct the bibliometric analyses. Most scientific publications that used UAV technology as a working tool have predominant applicability in photogrammetry, while GIS applications are found in publications dedicated to image processing, landslides, and cultural and archaeological heritage. We point out that from the point of view of international cooperation, at the level of institutions or countries, certain international organisations from the USA, China, and the central and northern European states have a high interest in this topic, and a low cooperation between academia and public administration is exhibited. The conclusion is represented by the apparent lack of framing of the results of UAS-GIS technologies usage into wider and more topical contexts, such as digital era governance, and also a reduced applicability of the research results.

Keywords: Unmanned Aircraft Systems; GIS; digitalisation; digital transformation; bibliometric analysis

\section{Introduction}

Digital era governance (DEG) is the descendant of New Public Management (NPM), a dominant set of theoretical and practical ideas related to management and governance from the 1985-2002 time period. DEG brings a new series of ideas and reform proposals, reaffirming the priorities neglected by NPM [1]. Digital era governance means an entire complex of changes, whose main core of concerns are the changes in IT and information management but develop simultaneously in more dimensions than in the previous case [1,2]. This concept is also associated with those of Public Value Management and New Public Governance, all three insisting on the cooperation in partnership, promoting governance, and innovation, and acknowledging the transformation potential of the digital technology [3]. According to Kosenkov et al. [4], digital governance has six dimensions: information dissemination, communication with citizens, service delivery, socioeconomic monitoring, advanced social analytics, and regulation of social life. 
A sustainable transition from digital government to digital governance is the transition from a technical structure to multiple processes at different levels. From the current perspective, digital government is seen as a part of the digital governance concept, together with the business aspects and those related to political decision making (digital democracy) [5]. In more specific terms, the impact of DEG practices is translated by a reconfiguration of the electronic channels where the agency (institution) "becomes its Web site" [1].

Within digital governance, Artificial Intelligence (AI) is one of the technologies that attracts the interest of public administration due to its potential impact [3]. Three additional important terms are frequently mentioned in DEG, especially in view of the thick confusion, i.e., "digitisation", "digitalisation", and "digital transformation" [6,7]. The first term, digitisation, refers to the audio or video conversion into a digital format, while the third one, digital transformation, contains, de facto, a series of digitalisation projects [8]. Digital technology is "implemented with the intent of establishing a communication infrastructure that connects various activities of the actor's various processes" [7]. Some studies show that adoption of information innovation is often incomplete, with low impact on administrative tasks [9]. Moreover, many local administrations adopt technical innovations such as websites, while their implementation is achieved as a unidirectional source of information for residents with access to the internet.

In the context of digital governance, we can also discuss the technologies that facilitate the visualisation of some extended surfaces, at low cost, from a variable altitude (low altitude airspace-LAA), the purchase of high utility data in decision making and management of highly complex operations, which also provide solutions in data processing and analysis. Starting from this challenge, in our paper we analysed how frequently and in what combination are the UAV/UAS and GIS technologies used in the context of digitalisation through the lens of bibliometric maps. The complementarity of UAS-GIS is given by the fact that the first technology is mainly intended to collect spatial data and the second to highlight them. Reference is made to most applications, otherwise each of these technologies develops other capabilities: UAS processes the sensor-based information and GIS takes over through GNSS applications or other types of sensors. Visualisation of the relevant affiliations of the paper authors, the frequency of the co-keywords, and the international cooperation network became relevant indicators for the scientific production associated with the use of GIS-UAS as a team.

Two research questions were formulated:

(1) When implemented, what are the main application sectors for the teaming of GISUAS/UAV in DEG?

(2) What is the scientific production associated with the use of GIS-UAS and the main attributes of the working tools used?

\subsection{Unmanned Aircraft Systems (UAS) and Unmanned Aircraft Vehicles (UAV)}

Unmanned Systems (US) or Vehicles (UV) are defined as electromechanical systems without a human operator [10]. US can be remote (by a remote pilot) or can navigate autonomously based on preprogrammed plans, generated in First-Party Apps or ThirdParty Apps [11,12] or in automatic, more dynamic, and more complex systems [13].

Unmanned Aircraft Systems (UAS), Unmanned Aerial Vehicles (UAV), Drones, or Remotely Piloted Aircraft Systems (RPAS) refer to the unmanned systems navigating in the air [14], capable of flying over hard-to-reach areas [15]. This study was based only on the references regarding civilian UAS, not those used in the military sector.

As the UAS application sectors diversify, their taxonomy also becomes more complex. So far, distribution into four main classes was proposed, based on embedded mechanism, power, user capabilities, and operating environment [16]. These make plausible the image of future smart cities where drone flights will become a normality, similar to road vehicles today [17], together with other technologies that include wireless sensor networks (WSNs), the Internet of Things (IoT), cloud computing, fog computing, and big data ana- 
lytics. Among the expected applications in the literature, based on the use of UAV/UAS technologies, we mention: traffic monitoring and management, health emergency services, disaster management, security and crowd monitoring, UAS-based infrastructure inspections, agriculture management and environmental monitoring, tourism support, UAS-based surveying, merchandise order delivery, UAS-aided wireless communication, UAS taxi, virtual retrofitting applications, cinematography, human-robot interaction-based applications, UAS-based fog computing, both for urban and for rural residential environments [18-21].

On the other hand, the UAS currently address some challenges such as the prevention of risks that define rural spaces or aspects regarding the quality of life and conservation of cultural heritage [22]. Furthermore, the applicability of the UAS technology is proved also in the case of ensuring their IoT sustainability, thus making efficient the energy consumption of some IoT devices for data transmission [23]. UAS contribute also to the configuration of the future 6G internet network, a component of the Internet of Everything (IoE), a new paradigm that provides ubiquitous connections, aerial intelligence, self-maintenance of communications, sensor powering, and deployment [24,25].

We believe that all these advantages of the UAS will be powerful enough to overcome all existing barriers (threats to the data privacy and security, lack of procedures, public perception, environmental, or even technical aspects), by implementing drones in the logistics industry $[17,26]$. Special attention is paid to Unmanned Aerial Vehicle Regulation Policies and Technologies in Urban Low Altitude [27], because the urban environment is the testing environment of most of the technological progress elements, in the context of complexity and diversity of needs that need to be solved. Use of UAS images and the structure in motion photogrammetry with stereo multi-view (SfM-MVS) enables rapid reconstructions of the surface geometry (digital elevation models, orthophotoplans) based on the achieved and overlapped images [14].

\subsection{Geographic Information Systems (GIS)}

Information gathered in digital format with the sensors carried by UAS, processed in photogrammetry software, become, most of the time, an alternative to existing topographic and planimetric maps. In addition, digital maps are often used in GIS and CAD applications for design analysis [14]; in this case, we refer to monitoring or data collection activities [17].

At the same time, GIS also represents a frontier technological discipline based on information theory, cybernetics, system engineering, and artificial intelligence [28], with established implications in land management, urban and rural planning, traffic management, and environmental management [29]. A more complex image of GIS applicability, as was already provided by Usmani et al., would include five domains, each with a few distinct subdomains, such as: (a) environmental and natural resource management, (b) decision system, (c) planning and engineering, (d) street network, and (e) facilities management. Another important aspect to pursue is also the positive impact of the large databases in the GIS industry, with beneficial results in all application sectors [30].

Aside from the partnership between UAS (mainly as data processing means) and GIS (means of spatial data storage, processing, and visualisation), the latter work instrument has multiple applications. It is worth mentioning that this teamwork is not established in all application sectors. Sometimes, even if the visualisation component has become more important over the last years, the main advantage of GIS derives from its capacity to conduct complex spatial analyses. A bibliometric analysis of spatial analyses in the 1950-2019 interval highlights the utility of this tool for ecology, geography, or interdisciplinary fields such as environmental sciences, public environmental and occupational health, and multidisciplinary geosciences [31].

Spatial analyses present a high degree of utility, belonging to the Spatial Multicriteria Evaluation (SME) or GIS Multicriteria Evaluation (GME) equation, one of the most valuable techniques for management planning and decision making [32,33]. Going further, one of the development tendencies of GIS is Question Answering (QA), a process for the 
identification of valid answers to the questions asked by the user in natural language. This implies that the analyst may interrogate certain pieces of spatial information regarding the use of geographical resources, without having the necessary knowledge for understanding the GIS working techniques [34] or the online access to a GIS environment by inexperienced users [35].

The sample outlined communities (smart cities/smart villages) would be GIS-based, while an enterprise architecture framework/EAF would be proposed for the smart cities, supported by a hybrid model based on GIS and graphic databases (GDB). Therefore, the augmented space model created is based on the principles of an augmented and virtual reality, which include, in turn, augmented systems, maps, images, and models [36]. Applicability of the GIS tools was also proven in the implementation of sustainable development principles for rural environments [37]. When it comes to spatial data, the development trend needs to be directed towards the infrastructure of spatial data activated in the cloud (SDI), due to the numerous advantages that they imply, including the possibility of integrating with the IoT [38].

If we refer to the need of managing a territory, the basis of a twin digital model is represented by Land Information System (LIS), whose key/basic component is the cadastral survey. This begins to manage 3D, 4D (time) [39], or even 5D (level of detail) information [40]. Today, an LIS cannot be imagined without the combined contribution of GIS (which provides a macro representation of the external environments of some buildings) and BIM (which focuses on the microscale representation of the buildings), which provides an overview of a built environment based on integrated data, supporting the transition towards the architecture, engineering, and construction industry (AEC) in the digital era [41]. Cooperation between BIM and GIS is not fruitful only for the maintenance of LIS, but also for the automation of construction, especially if we consider the accelerated evolution rhythm of robots [42].

Public health policies represent one of the sectors where the geographical aspects have an increased importance. GIS becomes, in this case, a decision instrument for the remediation of some aspects related to the geographical heterogeneity, neighbourhood effect, small population problem, health-care market delineation, and planning towards equality $[41,43]$. Consequently, web mapping made possible the transmission of data associated with the realtime monitoring of the COVID-19 crisis, at various detail scales [44].

GIS, considered among the important big data technologies, together with remote sensing imagery, social media data, crowdsourced data, and mobile data, can be easily used also in various disaster management phases and in resilience building or in the testing of some prediction models [45-48].

\section{Materials and Methods}

From a methodological point of view, literature analysis was based on several work stages, from data collection to data reclassification and the actual development of the bibliometric analyses (Figure 1). The Web of Science database was used due to the high visibility of the scientific publications but also due to the acknowledgment of their impact at international level. No other databases (Scopus, ERIH, etc.) were used in order to avoid the juxtaposition of publications. The VOSviewer 1.6.15 and Bibliometrix 3.1 (R-tool) software were used to conduct the bibliometric analyses and their visualisation. The main work stages used were:

(i) data collection, for which the following words were used as search criteria: "GIS" AND “UAV", "GIS" AND “UAS", "GIS" AND “Drone", "GIS" AND “RPAS" (Table 1). This was performed after the search for the "Digital era governance" AND "GIS" AND "UAV" criterion displayed no results. The initial selection criteria regarding the characteristics of these scientific publications took into consideration only the publications in English.

(ii) reclassification of data, a necessary step, given the fact that the literature search displayed 454 elements, exported in an Excel document, and that many of these 
elements were doubled ( $n=109$ doubled elements) (Table 1). A secondary filtering criterion was applied to the same studies, as the publications that were eliminated were incorrectly catalogued in the Web of Science database. The abbreviation used had a different connotation than that investigated or the keyword mentioned was written differently $(n=15)$. Table 1 highlights the frequency of using each of the four terms associated with drone and the cases where at least two terms are interrogated and selected. For each exported publication, the collected data were the title, authors' affiliation, abstract, keywords, year of publication, source, type of document, etc.

(iii) data visualisation, conducted by bibliometric maps associated with the investigated topics, by means of the cluster technique.

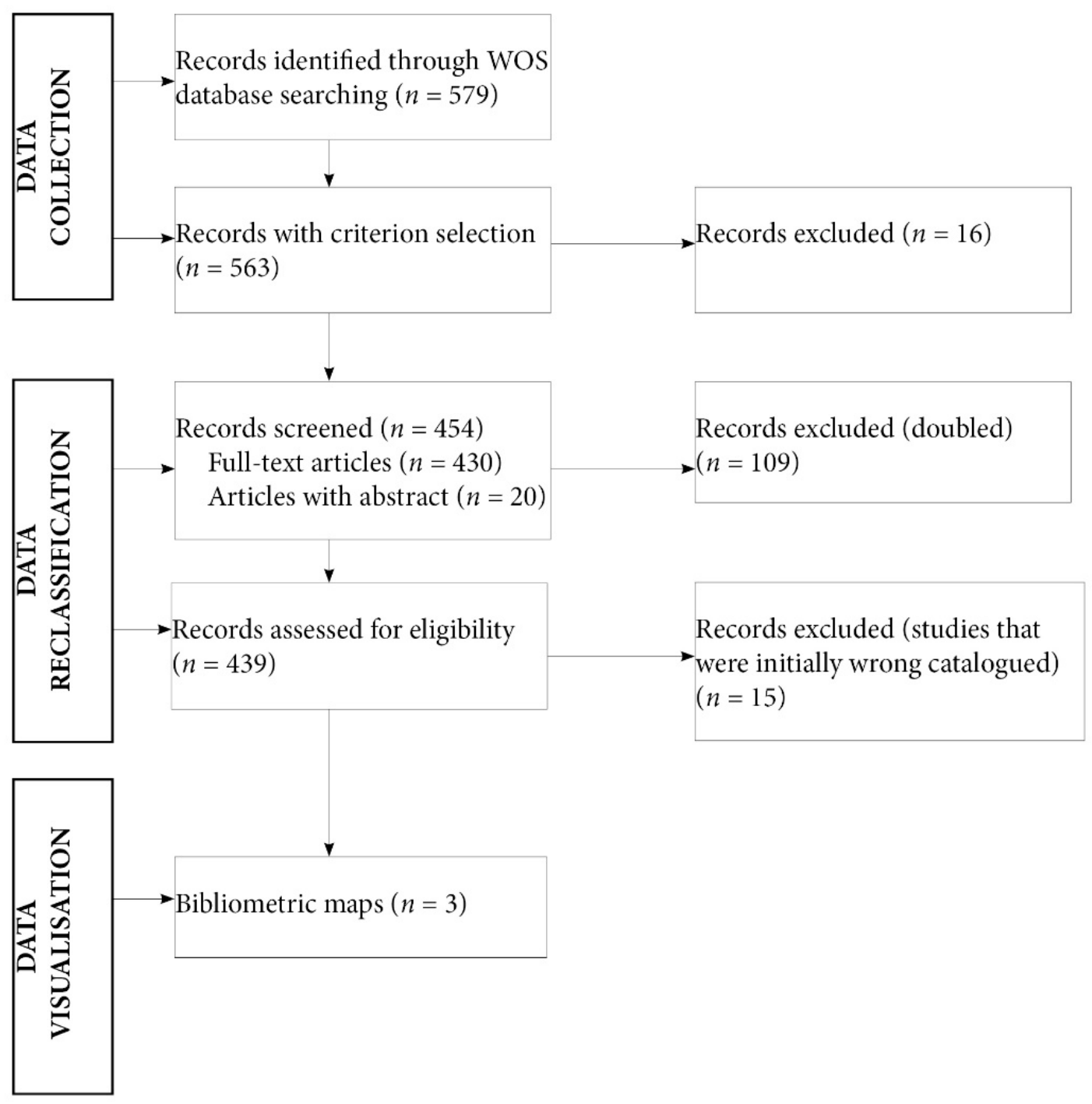

Figure 1. Flowchart describing the scientific literature. 
Table 1. The frequency of using the words associated with the filter criteria of the scientific publications, except GIS.

\begin{tabular}{|c|c|c|c|c|c|c|c|c|c|c|c|c|c|c|c|c|c|c|c|c|c|c|c|}
\hline \multirow{2}{*}{\multicolumn{2}{|c|}{ Terms }} & \multirow{2}{*}{ สิ่ } & \multirow{2}{*}{ สิิ } & \multirow{2}{*}{ ڤેे } & \multirow{2}{*}{ 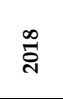 } & \multirow{2}{*}{ ลิे } & \multirow{2}{*}{ కั้ } & \multirow{2}{*}{ ปี้ } & \multirow{2}{*}{ تีّ } & \multirow{2}{*}{ ڤ్ } & \multirow{2}{*}{ ปี้ } & \multirow{2}{*}{ รี่ } & \multirow{2}{*}{ ڤั่ } & \multirow{2}{*}{ ఫ્సે } & \multirow{2}{*}{ ڤัे } & \multirow{2}{*}{ ڤે̀े } & \multirow{2}{*}{ ఊั่ } & \multirow{2}{*}{ కిิ } & \multirow{2}{*}{ ثั่ } & \multirow{2}{*}{ ఫิ } & \multirow{2}{*}{ ธิ่ } & \multicolumn{2}{|c|}{$\begin{array}{c}\text { Marginal } \\
\text { Row Totals }\end{array}$} \\
\hline & & & & & & & & & & & & & & & & & & & & & & No. & $\%$ \\
\hline $\begin{array}{l}\text { UAS } \\
\text { UAV }\end{array}$ & & $\begin{array}{c}3 \\
28\end{array}$ & $\begin{array}{c}4 \\
48\end{array}$ & $\begin{array}{l}1 \\
35\end{array}$ & $\begin{array}{c}3 \\
25\end{array}$ & $\begin{array}{c}3 \\
21\end{array}$ & $\begin{array}{l}3 \\
33\end{array}$ & $\begin{array}{l}4 \\
18\end{array}$ & $\begin{array}{l}2 \\
4\end{array}$ & $\begin{array}{c}2 \\
10\end{array}$ & 2 & $\begin{array}{l}1 \\
5\end{array}$ & 4 & 2 & 1 & 4 & 4 & 1 & 1 & 2 & 2 & $\begin{array}{l}26 \\
250\end{array}$ & $\begin{array}{l}5.7 \\
55.1\end{array}$ \\
\hline $\begin{array}{l}\text { UAV } \\
\text { Drone }\end{array}$ & & 10 & $\begin{array}{l}48 \\
15\end{array}$ & 21 & 17 & 14 & $\begin{array}{l}33 \\
8\end{array}$ & $\begin{array}{l}18 \\
7\end{array}$ & 1 & 1 & & & 4 & 2 & & 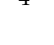 & 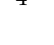 & & 1 & & & 4 & 20.7 \\
\hline $\begin{array}{l}\text { RPAS } \\
U A S \text { and } U A V\end{array}$ & & & & $\begin{array}{l}2 \\
2\end{array}$ & 1 & 2 & 3 & 1 & & 2 & & 1 & & & & & & & & & & $\begin{array}{c}2 \\
12\end{array}$ & $\begin{array}{l}0.4 \\
2.6\end{array}$ \\
\hline UAS and Drone & & & 3 & & 1 & 1 & 1 & & & & & & & & & & & & & & & & 3 \\
\hline UAV and Drone & & 5 & 12 & 7 & 10 & 5 & 9 & 1 & 1 & & & & & & & & & & & & & 50 & 11.0 \\
\hline$U A S$ and $U A V$ and & & 2 & 2 & 3 & 1 & 2 & & & & & 1 & & & & & & & & & & & $\begin{array}{l}6 \\
7\end{array}$ & $\begin{array}{l}1.5 \\
1.5\end{array}$ \\
\hline $\begin{array}{l}\text { UAS and UAV and } \\
\text { Drone and RPAS }\end{array}$ & & & & & & & & & 1 & & & & & & & & & & & & & 1 & 0.2 \\
\hline $\begin{array}{l}\text { Marginal } \\
\text { Columns Totals }\end{array}$ & $\underset{\%}{\mathrm{Nr} .}$ & $\begin{array}{l}48 \\
10.6\end{array}$ & $\begin{array}{l}84 \\
18.5\end{array}$ & $\begin{array}{c}71 \\
15.6\end{array}$ & $\begin{array}{l}60 \\
13.2\end{array}$ & $\begin{array}{l}48 \\
10.6\end{array}$ & $\begin{array}{l}57 \\
12.6\end{array}$ & $\begin{array}{l}31 \\
6.8\end{array}$ & $\begin{array}{c}9 \\
2.0\end{array}$ & $\begin{array}{l}15 \\
3.3\end{array}$ & $\begin{array}{c}3 \\
0.7\end{array}$ & $\begin{array}{l}7 \\
1.5\end{array}$ & $\begin{array}{c}4 \\
0.9\end{array}$ & $\begin{array}{c}2 \\
0.4\end{array}$ & $\begin{array}{c}1 \\
0.2\end{array}$ & $\begin{array}{c}4 \\
0.9\end{array}$ & $\begin{array}{c}4 \\
0.9\end{array}$ & $\begin{array}{c}1 \\
0.2\end{array}$ & $\begin{array}{c}1 \\
0.2\end{array}$ & $\begin{array}{c}2 \\
0.4\end{array}$ & $\begin{array}{c}2 \\
0.4\end{array}$ & $\begin{array}{l}454 \\
100\end{array}$ & 100 \\
\hline
\end{tabular}

The limitations of the study derive from the use of a single international database (Web of Science), but this does not mean that it underestimates the relevance.

\section{Results}

\subsection{Scientific Literature Profile}

The analysis of the 2052 keywords found in the 454 scientific publications associated with the investigated topics, provided information related to their main content. Of the total, only 81 keywords met the minimum threshold of five words in terms of frequency, thus resulting in seven clusters (Figure 2, Table 2). The size of the nodes reflected the frequency of the keywords, while the thickness of the line is directly proportional to the interrelation degree of the keywords. Most representative clusters were those dominated by UAV (cluster seven, with 79 links) and GIS (cluster two, with 76 links), followed by the clusters governed by photogrammetry (cluster six) and remote sensing (cluster one). While most of the scientific publications use the UAV technology as a working tool predominantly in photogrammetry and DEM generation (cluster seven), GIS applications were found to a greater extent in publications dedicated to image processing, landslides, cultural and archaeological heritage.

Table 2. Clusters of keywords.

\begin{tabular}{|c|c|c|}
\hline Cluster & $\begin{array}{l}\text { Number of } \\
\text { Keywords }\end{array}$ & Selected Keywords \\
\hline 1 & 14 & $\begin{array}{l}\text { Airborne LIDAR, algorithm, forest fire, impact, LIDAR, model, } \\
\text { parameter, rates, reflectance, remote sensing, risk assessment, } \\
\text { satellite, satellite imagery, simulation }\end{array}$ \\
\hline 2 & 13 & $\begin{array}{l}\text { Archaeological site, area, city, cultural heritage, DEM, erosion, GIS, } \\
\text { GPS, hazard, image processing, landslide, orthophoto, river }\end{array}$ \\
\hline 3 & 13 & $\begin{array}{l}\text { Classification, crop, design, NDVI, precision agriculture, resolution, } \\
\text { sensor, system, UAS, vegetation, water, webgis, yield }\end{array}$ \\
\hline 4 & 12 & $\begin{array}{l}\text { Dynamics, evolution, forest, GIS analysis, imagery, monitoring, } \\
\text { prediction, RPAS, SFM, slope, susceptibility, UAV photogrammetry }\end{array}$ \\
\hline 5 & 11 & $\begin{array}{l}\text { Augmented reality, BIM, biodiversity, conservation, ecology, } \\
\text { information, management, morphology, restoration, technology, } \\
\text { UAV imagery }\end{array}$ \\
\hline 6 & 10 & $\begin{array}{l}\text { 3D accuracy, basin, DSM, photogrammetry, point cloud, } \\
\text { reconstruction, soil erosion, tool, topography }\end{array}$ \\
\hline 7 & 8 & $\begin{array}{l}\text { 3D GIS, 3D model, 3D reconstruction, archaeology, drone, } \\
\text { landscape, mapping, UAV }\end{array}$ \\
\hline
\end{tabular}




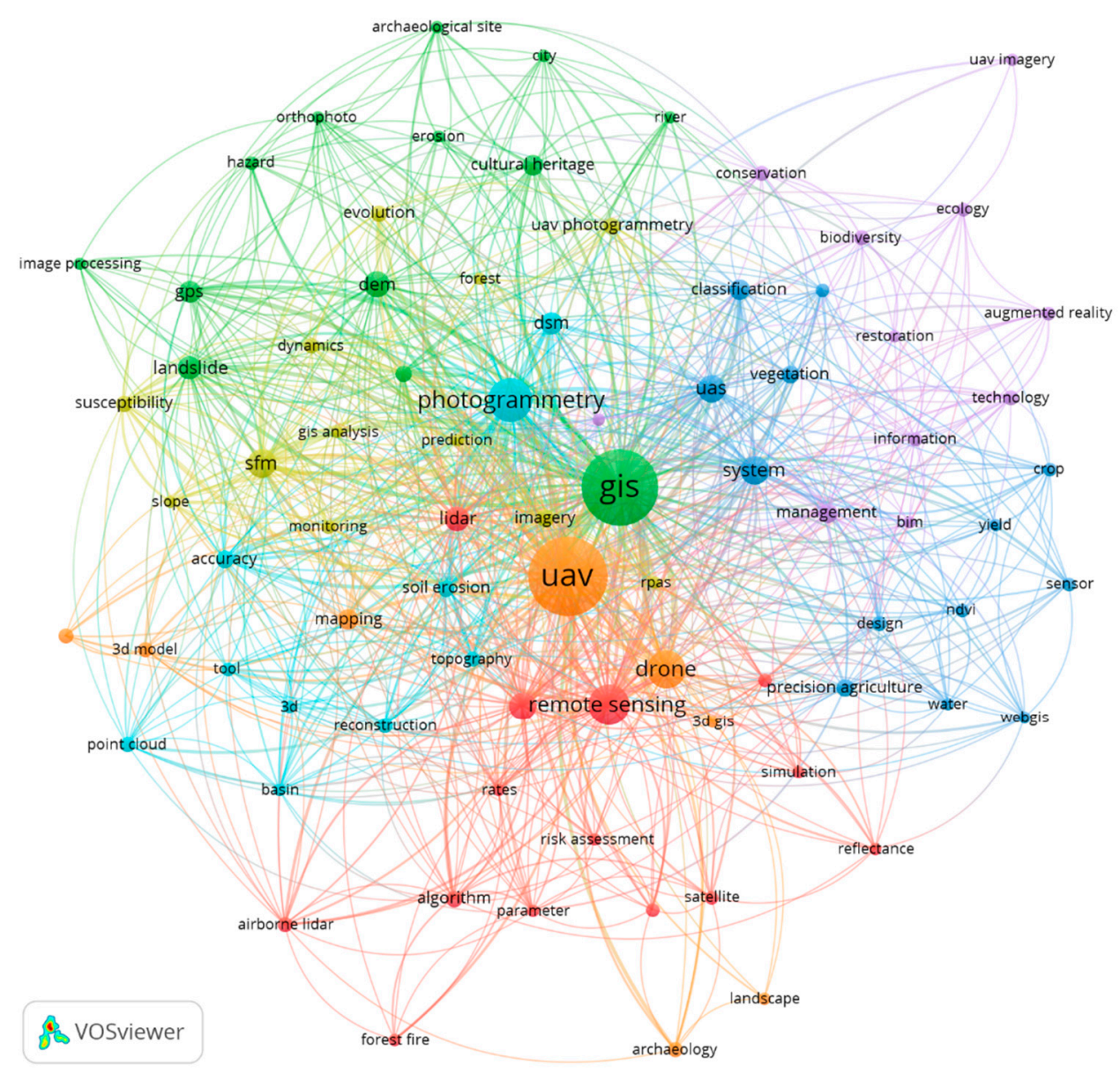

Figure 2. Co-keyword network visualisation.

The reporting of the analysed studies to DEG or to associated concepts is poor, no matter what field we are talking about (Table 3). With the exception of "digitisation" and "digitalisation" (which are often confused), the others appear in few or even no articles. The situation has two explanations: (a) the authors of the studies do not intend to report by integrating the results to wider known frameworks (DEG, Digitalisation); (b) other newer concepts (Digital Twin, Internet of Things), in full theoretical development, hardly reach the "table" of overspecialised authors. A logical solution in such situations is the collaboration between the UAS and GIS operators, the specialists in public management, a situation in which both camps would win.

\subsection{Cooperation Network}

Another important indicator associated with the scientific production is that related to international cooperation created on a certain research topic, demonstrating on the one hand the existing research potential, and, on the other hand, being a benchmark for the identification of possible research networks. The relationships between the keywords, countries, and sources were viewed by means of the Sankey diagram (Three Fields Plot) (Figure 3). In this case, the most representative elements were highlighted on the graphic by means of coloured triangles. The height of a rectangle depends on the intensity of the existing relationships between the pursued elements. We signal the fact that, although at institutional or country level, certain international organisations stand out, from the USA, China, and the central and north European states, we notice a high polarisation coming from Romanian researchers, who, starting in 2015, have been using more and more the GIS-UAV combination of technologies. 
Table 3. The number of articles in which the concept of DEG or associated terms appears.

\begin{tabular}{|c|c|c|c|c|c|c|c|c|c|c|c|c|c|}
\hline Terms & 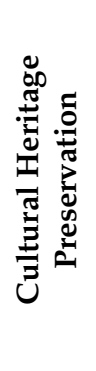 & $\begin{array}{l}\vec{D} \\
\stackrel{D}{0} \\
\stackrel{0}{0} \\
\text { I }\end{array}$ & 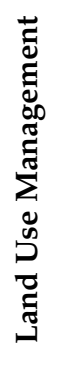 & 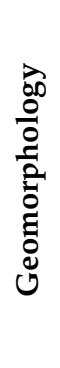 & 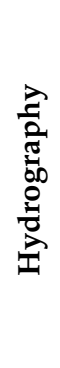 & & 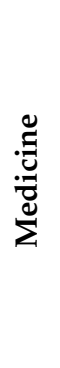 & 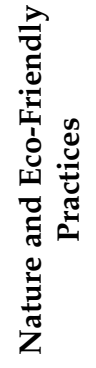 & 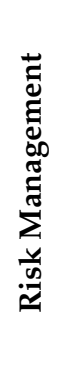 & 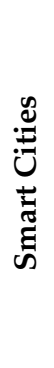 & 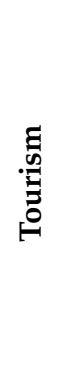 & 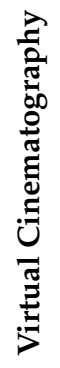 & 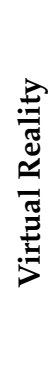 \\
\hline \multicolumn{14}{|l|}{$\begin{array}{l}\text { e-Government } \\
\text { e-Governance }\end{array}$} \\
\hline Governance & & & & & & & & 1 & & & & & 1 \\
\hline $\begin{array}{c}\text { Digital Governance } \\
\text { Digital era }\end{array}$ & & & & & & & & & & & & & \\
\hline \multicolumn{14}{|l|}{ Digital era governance } \\
\hline Digitisation & 4 & & 5 & 3 & 5 & 3 & & 5 & 1 & & & & \\
\hline Digitalisation & 2 & 1 & 1 & & 1 & 1 & & & & & & & 1 \\
\hline \multicolumn{14}{|l|}{ Digital transformation } \\
\hline Big Data & 3 & & 1 & 2 & 1 & & & 2 & & 2 & & & \\
\hline Artificial Intelligence & & & 1 & 2 & 1 & 1 & & 2 & 1 & & & & 1 \\
\hline Digital Twin & & & & & & & & & & & & & 1 \\
\hline Internet of Things & & & 2 & & & & & & & 1 & & & \\
\hline
\end{tabular}

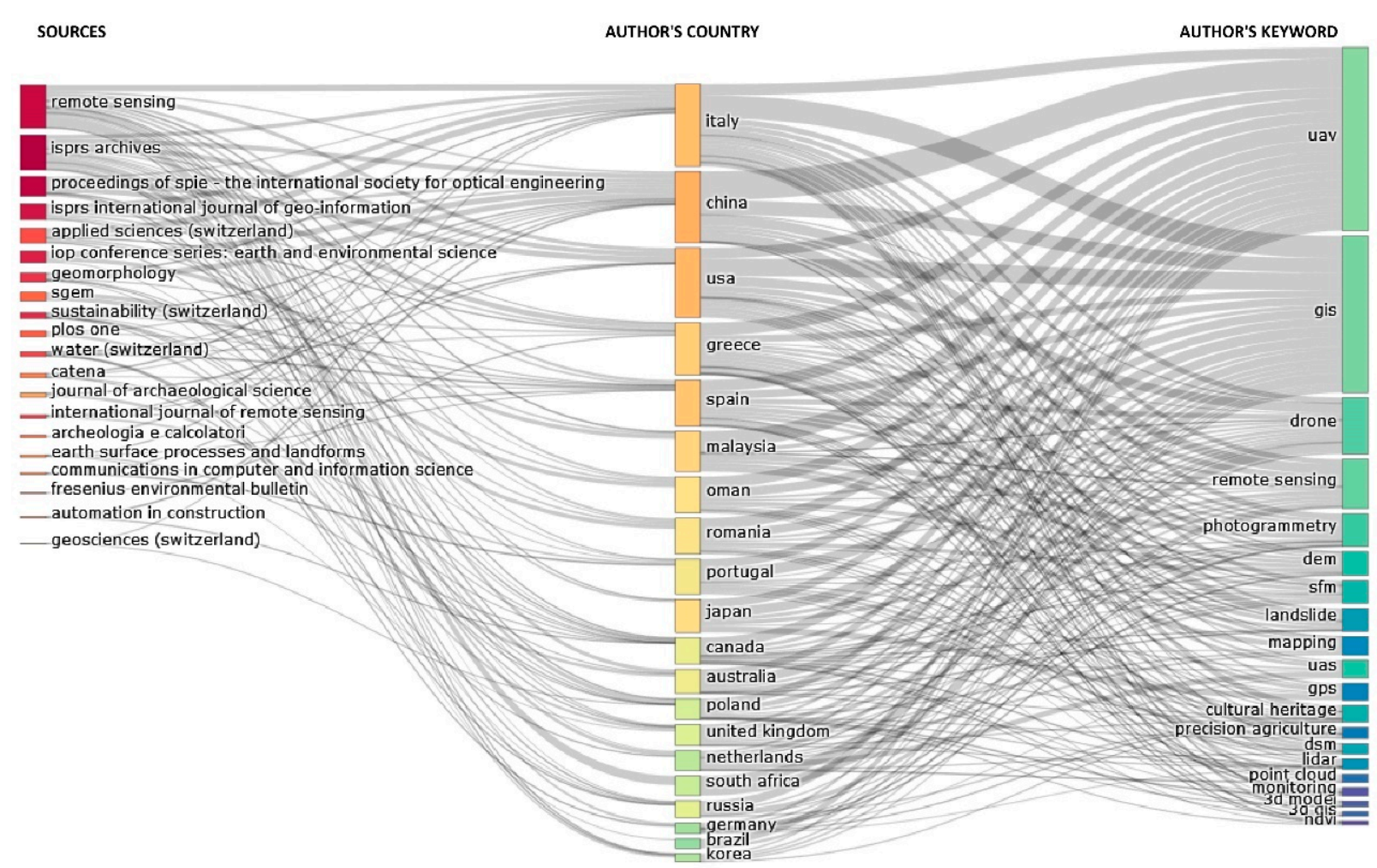

Figure 3. Relations between author keywords (left), countries (middle), and sources (right).

Of the 107 states that have cooperated in the drafting of at least one scientific publication, we notice an increased interest for the approach of GIS and UAV technologies among some researchers in China and the USA or other European states (Italy, Switzerland, and The Netherlands) or Italy and other central-northern European states (Figure 4). The same 
trend is similar for the affiliations of the authors (Figure 5). A lack of cooperation between academic professionals and government entities was also highlighted.

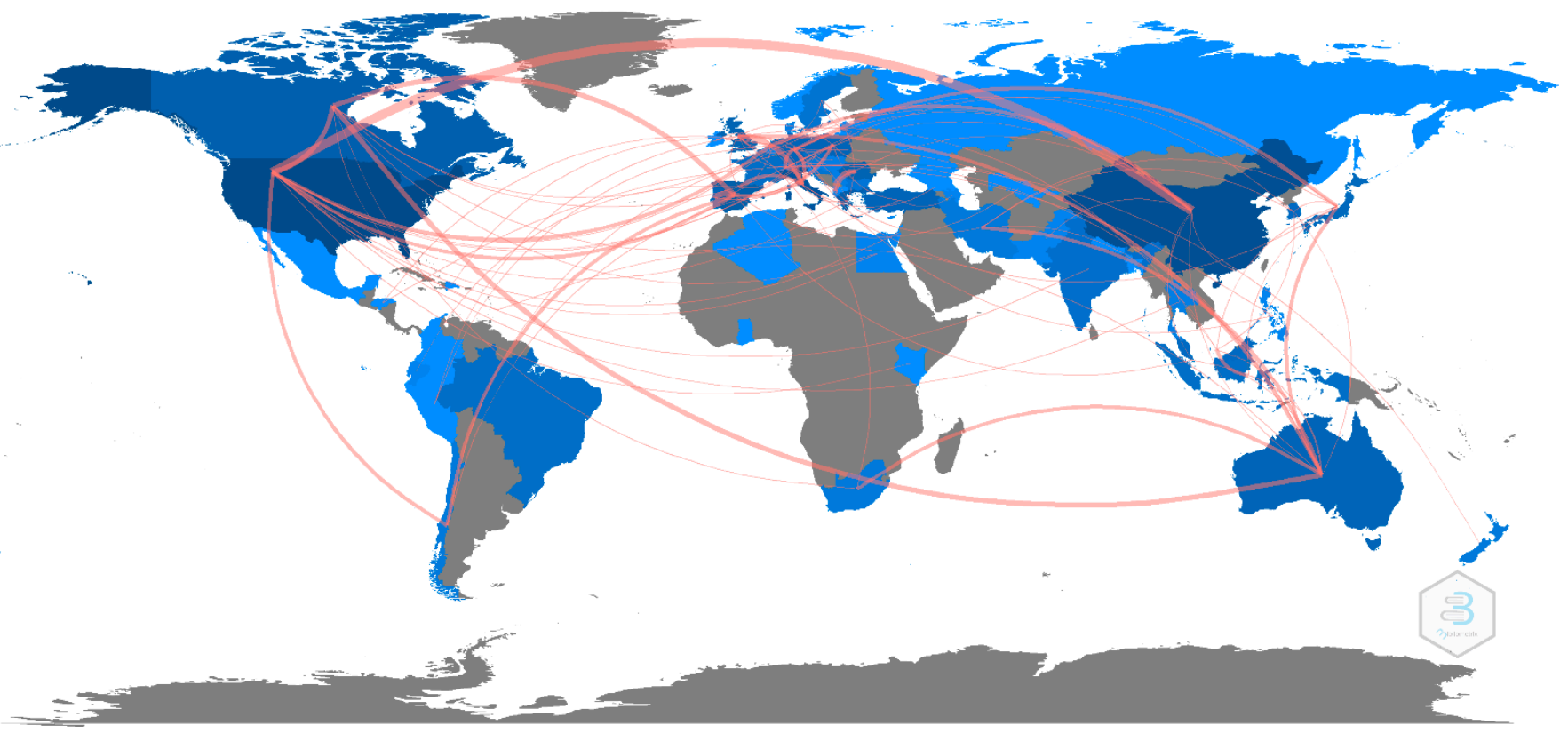

Figure 4. Map of world collaboration.

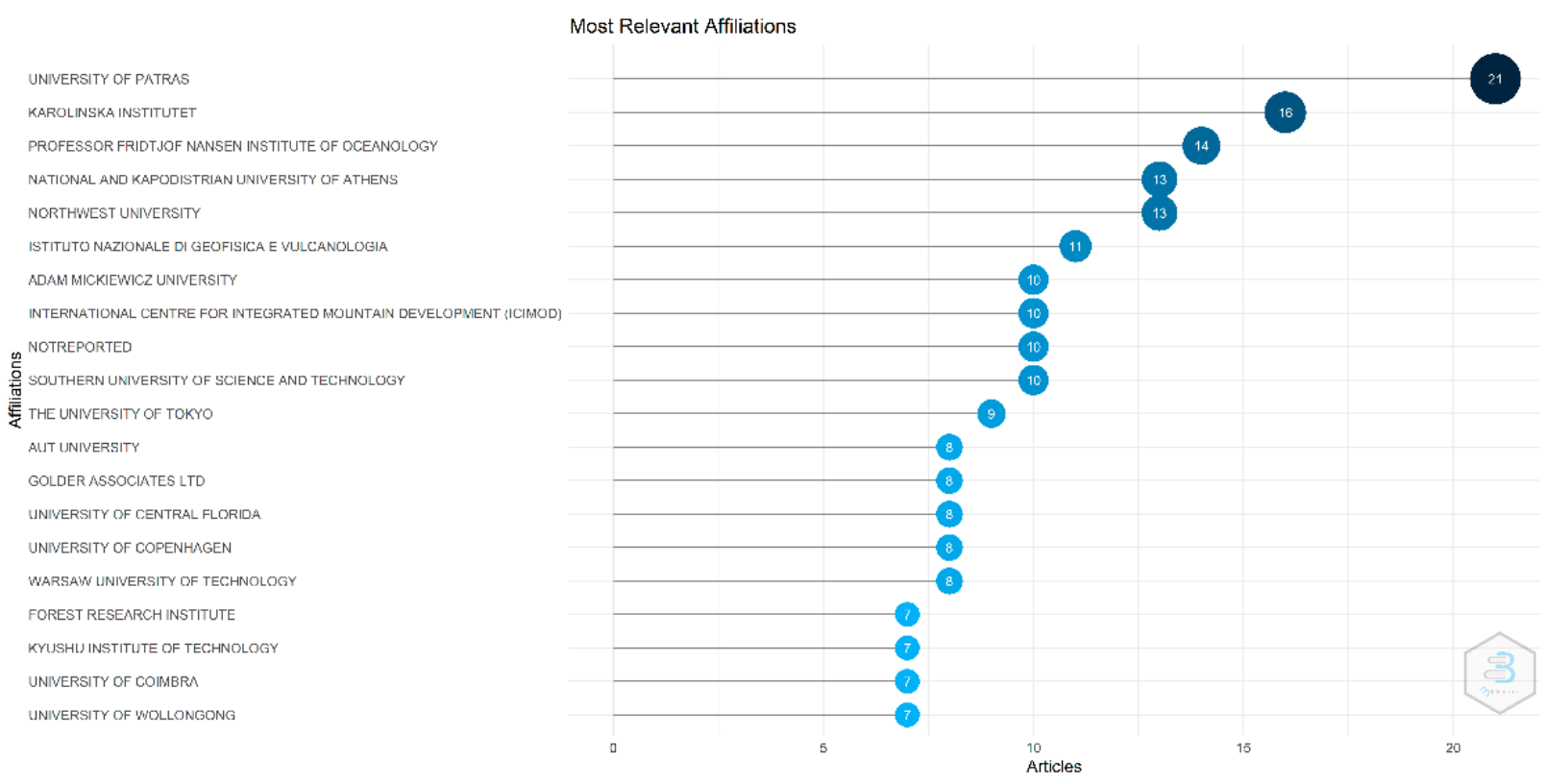

Figure 5. Map of the most relevant affiliations of the authors.

\section{Discussion}

In order for the digital government to become digital governance, some internal aspects (creation of a decision-making culture based on the data at administrative level) need to be considered, together with some external ones (governance of various stakeholders that are meant to integrate the various data sources). Another challenge for digital government that is valid also for digital governance is represented by Big Data implementation. For this undertaking, the number of scientists that know how to work with such data is limited, the management technologies are not mature enough, and the resources meant to create technologies and talents are scarce [5]. 
The relationship between the dimension of the department in an institution and the administrative capacity has been demonstrated for one part of U.S. cities, where it was proven that the implementation of the open data platform varied depending on the resources of the department [9]. In the rural environment, where the overall administration capacity is similar to a department of a local urban administration, the reduction in digital gaps between the urban and the rural environment is all the more necessary [49].

Today, more and more researchers use the combination of UAV and GIS technologies for the mapping of some territorial elements, for the testing of some prediction models, creation of evolution scenarios, 3D modelling of space objects, etc. (Table 4). In summary, the main application sectors of these technologies refer to:

- the preservation of cultural heritage, from the mapping of various cultural landscape elements, either applied to some ancient civilisations or to some contemporary cultural landscape, to the 3D modelling of some heritage assets, mostly found in archaeological sites;

- forestry, through the testing of some applications designed to identify the areas of illegal cutting, fires, or biomass resources;

- $\quad$ land use management, focused mostly on the testing of some agricultural prediction models, but also on land favourability analyses for certain crops or monitoring of various parameters that can influence the stages of crop growth;

- $\quad$ risk management, including, the testing of possible models for the monitoring and prediction of some extreme phenomena and postdisaster scenarios, on the other hand;

- geomorphology, where there is a propensity of scientists to map landslide areas and, to a lesser extent, for the identification of other geomorphological processes, among which earthquakes are the most common;

- $\quad$ engineering, infrastructure maintenance works, and estimation of new energy sources;

- medicine, where the large advantage of drone usage is the coverage of less-accessible areas, which facilitates the saving of lives;

- $\quad$ tourism, with 3D modelling or creation of virtual tours;

- environmental-friendly practices intended to map the ecosystem services of some areas, to identify the pollution sources or invasive species, or even to assess the noise-impact.

Table 4. Main content of the investigated scientific publications (2016-2021).

\begin{tabular}{|c|c|c|c|c|}
\hline Application Fields & Specific Contents & $\begin{array}{l}\text { Methodological Tools } \\
\text { (UAV, Sensors, GIS) }\end{array}$ & Location & References \\
\hline \multirow{6}{*}{$\begin{array}{l}\text { Cultural heritage } \\
\text { preservation }\end{array}$} & $\begin{array}{l}\text { 3D archaeological or } \\
\text { architectural } \\
\text { reconstruction }\end{array}$ & $\begin{array}{c}\text { UAV (DJI Phantom 4, DJI } \\
\text { Phantom } 3 \text { Advanced, DJI } \\
\text { Phantom } 3 \text { Pro), LiDAR, GIS } \\
\text { (QGIS, City Engine, ArcGIS 10.3), } \\
\text { Google Earth }\end{array}$ & $\begin{array}{l}\text { Romania, China, Italy, } \\
\text { Bulgaria, Malaysia, } \\
\text { Portugal, Ireland, } \\
\text { Australia, Russia }\end{array}$ & [50-60] \\
\hline & $\begin{array}{c}\text { Mapping cultural } \\
\text { landscapes (Maya or } \\
\text { Amerindian landscapes, } \\
\text { open spaces) }\end{array}$ & $\begin{array}{c}\text { UAV (DJI Phantom 4, DJI } \\
\text { Phantom 2, DJI Mavic Pro, eBee } \\
\text { Plus RTK-PPK), LiDAR, GIS } \\
\text { (QGIS, ArcGIS 10.3, 3D GIS), } \\
\text { GRASS }\end{array}$ & $\begin{array}{c}\text { Mexico, Italy, Dominican } \\
\text { Republic, Spain, China, } \\
\text { Palestine, USA, Australia, } \\
\text { Slovakia }\end{array}$ & [61-70] \\
\hline & $\begin{array}{c}\text { Creating viewshed } \\
\text { analysis }\end{array}$ & UAV, GIS & Peru & {$[71]$} \\
\hline & $\begin{array}{c}\text { Mapping archaeological } \\
\text { sites }\end{array}$ & $\begin{array}{c}\text { UAV (SenseFly eBee, DJI } \\
\text { Phantom } 4 \text { K, DJI Mavic Pro), } \\
\text { LiDAR, GIS (QGIS) }\end{array}$ & $\begin{array}{c}\text { Turkey, Chile, } \\
\text { Afghanistan, Italy, SUA, } \\
\text { Greece, South Africa, } \\
\text { Spain }\end{array}$ & [72-82] \\
\hline & $\begin{array}{l}\text { Building facade } \\
\text { inspections }\end{array}$ & UAV, GIS (2D GIS) & $\mathrm{N} / \mathrm{A}$ & [28] \\
\hline & $\begin{array}{c}\text { Extracting road surface } \\
\text { distress }\end{array}$ & DJI GS RTK, GIS & Turkey & [83] \\
\hline
\end{tabular}


Table 4. Cont.

\begin{tabular}{|c|c|c|c|c|}
\hline Application Fields & Specific Contents & $\begin{array}{l}\text { Methodological Tools } \\
\text { (UAV, Sensors, GIS) }\end{array}$ & Location & References \\
\hline \multirow{5}{*}{ Forestry } & $\begin{array}{l}\text { Monitoring uncontrolled } \\
\text { forest }\end{array}$ & UAV, GIS (ArcGIS, QGIS) & Poland, New Zealand & {$[84,85]$} \\
\hline & 3D forest modelling & $\begin{array}{c}\text { UAV (DJI S800, DJI Mavic Pro), } \\
\text { GIS (ArcGIS) }\end{array}$ & $\begin{array}{c}\text { Norway, Czech Republic, } \\
\text { USA }\end{array}$ & {$[86,87]$} \\
\hline & $\begin{array}{l}\text { Estimating the biomass } \\
\text { of riparian forests }\end{array}$ & $\begin{array}{l}\text { SenseFly eBee, RGB SenseFly } \\
\text { SODA, GIS }\end{array}$ & Portugal & {$[88,89]$} \\
\hline & $\begin{array}{l}\text { Monitoring crop factors, } \\
\text { parameters, attributes }\end{array}$ & $\begin{array}{l}\text { UAS (DJI Phantom, DJI S1000, } \\
\text { DJI Inspire 1, AF1000), RGB and } \\
\text { Thermal sensors, GIS (ArcGIS) }\end{array}$ & $\begin{array}{l}\text { Greece, Poland, China, } \\
\text { Saudi Arabia, Czech } \\
\text { Republic, Taiwan }\end{array}$ & [90-97] \\
\hline & Assessing land suitability & $\begin{array}{c}\text { Supercam S250F UAV, GIS } \\
\text { (ArcGIS 10) }\end{array}$ & Russia, Italy & [98] \\
\hline \multirow{5}{*}{$\begin{array}{l}\text { Land use } \\
\text { management }\end{array}$} & Land cover classification & $\begin{array}{l}\text { UAV (RPAS eBee), GIS (ArcGIS), } \\
\text { Google Earth }\end{array}$ & $\mathrm{N} / \mathrm{A}$ & [99-101] \\
\hline & $\begin{array}{l}\text { Improving farming } \\
\text { practices }\end{array}$ & DJI Matrice 100, GIS & Greece, Russia & {$[102,103]$} \\
\hline & $\begin{array}{l}\text { Developing predictive } \\
\text { agricultural models }\end{array}$ & $\begin{array}{l}\text { UAV (DJI Phantom 4, DJI } \\
\text { Matrice 210 V2, DJI Phantom } 3 \\
\text { professional, DJI Phantom 2, DJI } \\
\text { Inspire 1), GIS (QGIS), GRASS }\end{array}$ & $\begin{array}{l}\text { Portugal, Italy, Greece, } \\
\text { Ecuador }\end{array}$ & [104-109] \\
\hline & $\begin{array}{l}\text { Assessing tundra } \\
\text { degradation }\end{array}$ & $\begin{array}{l}\text { Supercam S 250, GIS } \\
\text { (ArcGIS 10.2) }\end{array}$ & Russia & [110] \\
\hline & $\begin{array}{l}\text { Monitoring erosion or } \\
\text { landslide activity }\end{array}$ & $\begin{array}{l}\text { UAV (Pegasus F-1000, DJI Mavic } \\
2 \text { Pro, DJI Matrice 600, DJI } \\
\text { Phantom 4, GIS Velodyne } \\
\text { VLP-16, RPAS, DJI Phantom 2, } \\
\text { AscTec Falcon, ATyges FV-8), } \\
\text { LiDAR, Micasense RedEdge } \\
\text { Sensor, GIS (SAGA GIS, QGIS } \\
\text { 3.8., Quantum GIS, ArcGIS 10.2, } \\
\text { 10.5), GRASS }\end{array}$ & $\begin{array}{c}\text { Nepal, Iran, China, } \\
\text { Greece, Indonesia, } \\
\text { Russia, Italy, Canada, } \\
\text { Saudi Arabia, Czech } \\
\text { Republic, Romania, } \\
\text { Spain }\end{array}$ & [111-132] \\
\hline \multirow[t]{6}{*}{ Geomorphology } & Monitoring topography & $\begin{array}{l}\text { UAV (DJI Phantom } 2 \text { Vision+, } \\
\text { DJI Phantom } 4 \text { Pro), GIS } \\
\text { (ArcMAP 10.6) }\end{array}$ & $\begin{array}{l}\text { Norway, Greenland, } \\
\text { Indonesia }\end{array}$ & [133-135] \\
\hline & $\begin{array}{l}\text { Monitoring different } \\
\text { geomorphological } \\
\text { processes (debris } \\
\text { accumulation, fluvial } \\
\text { forms, earthquakes) }\end{array}$ & $\begin{array}{l}\text { UAV (DJI Inspire } 1 \text { v2.0, eBee } \\
\text { Plus RTK, DJI Mavic Pro 2, DJI } \\
\text { Phantom 2), LiDAR, GIS (QGIS } \\
\text { 3, ArcGIS), Google Earth }\end{array}$ & $\begin{array}{l}\text { Poland, Brazil, Greece, } \\
\text { Portugal, Austria, Italy, } \\
\text { USA, Canada }\end{array}$ & [136-145] \\
\hline & $\begin{array}{l}\text { Mapping glacial-related } \\
\text { landforms }\end{array}$ & DJI Phantom, GIS & Norway & {$[146,147]$} \\
\hline & $\begin{array}{l}\text { Mapping volcanic } \\
\text { processes }\end{array}$ & $\begin{array}{c}\text { UAV (Blade } 350 \text { QX2, DJI } \\
\text { Phantom 4), GIS (ArcGIS Pro, } \\
\text { ArcGIS 10.2) }\end{array}$ & USA, New Zealand & {$[148,149]$} \\
\hline & Flood modelling & $\begin{array}{c}\text { UAS (SenseFly eBee, DJI } \\
\text { Phantom } 3 \text { Professional), GIS }\end{array}$ & $\begin{array}{l}\text { Central Asia, Spain, } \\
\text { Greece, Turkey, China }\end{array}$ & [150-153] \\
\hline & $\begin{array}{l}\text { Mosquito disease } \\
\text { mitigation }\end{array}$ & $\begin{array}{c}\text { Multispectral sensor MicaSense, } \\
\text { Drone, GIS }\end{array}$ & Australia & [154] \\
\hline \multirow[t]{3}{*}{ Hydrography } & $\begin{array}{l}\text { Monitoring the batimetry } \\
\text { and the surface area of } \\
\text { reservoirs }\end{array}$ & $\begin{array}{c}\text { UAV (Droning D650, Droning } \\
\text { D-820, WingtraOne, DJI } \\
\text { Phantom IV Pro, BRV-03F), GIS } \\
\text { (ArcGIS 1.3.2.) }\end{array}$ & Spain, Bulgaria & [155-157] \\
\hline & $\begin{array}{l}\text { Restoration of freshwater } \\
\text { inflows for wetlands }\end{array}$ & $\begin{array}{c}\text { Quadcopter (NAZA M V2), GIS } \\
\text { (ArcGIS 10.6) }\end{array}$ & USA & [158] \\
\hline & $\begin{array}{l}\text { Monitoring marine and } \\
\text { coastal activities }\end{array}$ & $\begin{array}{c}\text { UAV (DJI Mavic Pro), GIS } \\
\text { (ArcGIS) }\end{array}$ & $\begin{array}{l}\text { Cyprus, Scotland, Spain, } \\
\text { Portugal, Greece, India }\end{array}$ & [159-165] \\
\hline
\end{tabular}


Table 4. Cont.

\begin{tabular}{|c|c|c|c|c|}
\hline Application Fields & Specific Contents & $\begin{array}{l}\text { Methodological Tools } \\
\text { (UAV, Sensors, GIS) }\end{array}$ & Location & References \\
\hline \multirow{5}{*}{ Engineering } & $\begin{array}{l}\text { Modelling different } \\
\text { infrastructure works }\end{array}$ & UAV, GIS & Poland, Greece & [166-168] \\
\hline & $\begin{array}{l}\text { Designing emergency } \\
\text { maps }\end{array}$ & $\begin{array}{l}\text { UAV (DJI Phantom } 4 \text { Pro), } \\
\text { CMOS sensors, GIS (ArcMap } \\
\text { 10.5, ArcGIS, 2D-GIS), } \\
\text { Google Earth }\end{array}$ & Italy, Greece & [169-172] \\
\hline & $\begin{array}{l}\text { Supervising road and } \\
\text { railway maintenance } \\
\text { works }\end{array}$ & $\begin{array}{l}\text { UAV (Cumulus One, md4-1000 } \\
\text { drones), GIS (ArcGIS) }\end{array}$ & Malaysia, Japan, Croatia & {$[173,174]$} \\
\hline & $\begin{array}{l}\text { Digital surveying of } \\
\text { pipelines }\end{array}$ & UAV, GIS & $\mathrm{N} / \mathrm{A}$ & [175] \\
\hline & $\begin{array}{l}\text { Estimating solar and } \\
\text { wind energy potential }\end{array}$ & $\begin{array}{l}\text { UAV (Gatewing X100), GIS } \\
\text { (ArcGIS), GRASS } \\
\text { UAV (SenseFly eBee, DJI }\end{array}$ & Colombia & [176-178] \\
\hline \multirow{6}{*}{ Medicine } & Mapping quarries & $\begin{array}{l}\text { Phantom } 3 \text { Pro), RGB and } \\
\text { multispectral sensors, GIS, } \\
\text { Google Earth }\end{array}$ & Spain, Greece & {$[179,180]$} \\
\hline & Cadastre mapping & DJI Phantom 4 Pro, GIS (QGIS) & India & {$[181,182]$} \\
\hline & $\begin{array}{l}\text { Testing high-incidence } \\
\text { areas }\end{array}$ & $\begin{array}{c}\text { DJI Matrice Pro 600, GIS } \\
\text { (ArcGIS Pro) }\end{array}$ & Sweden & [183] \\
\hline & $\begin{array}{l}\text { Testing medical drones } \\
\text { for emergency purpose }\end{array}$ & UAV, GIS (ArcGIS 10) & USA, Sweden & [184-186] \\
\hline & $\begin{array}{l}\text { Monitoring coastal } \\
\text { landscapes }\end{array}$ & $\begin{array}{c}\text { UAV (DJI Phantom } 4 \text { Pro, DJI } \\
\text { Zenmuse X3-FC350), GIS } \\
\text { (QGIS v.2.18) }\end{array}$ & Italy, Bulgaria, Iran & [187-189] \\
\hline & $\begin{array}{l}\text { Detecting invasive } \\
\text { species }\end{array}$ & $\begin{array}{l}\text { UAV (DJI Phantom 4, DJI Inspire } \\
\text { 2), Multispectral sensor (Parrot } \\
\text { Sequoia), GIS (QGIS 2.18) }\end{array}$ & Germany, China, Canada & [190-192] \\
\hline \multirow{2}{*}{$\begin{array}{l}\text { Nature and } \\
\text { eco-friendly } \\
\text { practices }\end{array}$} & $\begin{array}{c}\text { Monitoring and } \\
\text { modelling environmental } \\
\text { contamination (landfills, } \\
\text { pollution sources) }\end{array}$ & $\begin{array}{l}\text { UAV (Trimble UX5, DJI Phantom } \\
\text { 4), GIS, Methane sensor (TGS } \\
\text { 2611/MQ-2) }\end{array}$ & $\begin{array}{l}\text { UK, China, Ukraine, } \\
\text { Germania, Lithuania, } \\
\text { China }\end{array}$ & [193-200] \\
\hline & $\begin{array}{l}\text { Monitoring ecosystem } \\
\text { services }\end{array}$ & $\begin{array}{c}\text { UAV (DJI Phantom } 4 \text { Advanced, } \\
\text { DJI Phantom } 3 \text { Pro, DJI Matrice } \\
\text { M100), GIS (ArcGIS, QGIS), } \\
\text { Google Earth }\end{array}$ & $\begin{array}{c}\text { Russia, South Africa, } \\
\text { USA, China, Germany, } \\
\text { Chile, Serbia, Canada, } \\
\text { Australia, Republic of } \\
\text { Korea }\end{array}$ & [201-213] \\
\hline \multirow{5}{*}{ Risk management } & $\begin{array}{c}\text { Measuring } \\
\text { microtopography }\end{array}$ & DJI Phantom 4 Pro, GIS (ArcGIS) & Canada & [214] \\
\hline & $\begin{array}{l}\text { Asssessing the } \\
\text { noise-impact }\end{array}$ & UAV, GIS & Croatia & {$[215,216]$} \\
\hline & Monitoring forest fires & UAV (CESSNA 310Q), GIS & $\begin{array}{l}\text { Croatia, Netherlands, } \\
\text { Greece, Indonesia }\end{array}$ & [217-219] \\
\hline & $\begin{array}{l}\text { Monitoring preventive } \\
\text { actions (flood prone } \\
\text { areas, tsunami } \\
\text { evacuation plans) }\end{array}$ & UAV, GIS, Google Earth & $\begin{array}{l}\text { Afghanistan, Nepal, } \\
\text { Romania, Haiti, USA, } \\
\text { Taiwan, Italy, France }\end{array}$ & [220-225] \\
\hline & $\begin{array}{l}\text { Testing scenarios for } \\
\text { real-life postdisaster } \\
\text { situations }\end{array}$ & UAV, GIS & Brazil, Italy & [226] \\
\hline Smart cities & $\begin{array}{l}\text { Controlling traffic } \\
\text { management }\end{array}$ & $\begin{array}{l}\text { UAV (Topcon Falcon 8), Sensors } \\
\text { (MEMS-based IMU), GIS }\end{array}$ & Slovenia & [227-229] \\
\hline
\end{tabular}


Table 4. Cont.

\begin{tabular}{|c|c|c|c|c|}
\hline Application Fields & Specific Contents & $\begin{array}{l}\text { Methodological Tools } \\
\text { (UAV, Sensors, GIS) }\end{array}$ & Location & References \\
\hline \multirow{3}{*}{ Tourism } & $\begin{array}{l}\text { Examining the profile of } \\
\text { UAV photographers }\end{array}$ & UAV (DJI), GIS & $\mathrm{N} / \mathrm{A}$ & [230] \\
\hline & $\begin{array}{l}\text { Creating touristic story } \\
\text { maps }\end{array}$ & $\begin{array}{c}\text { DJI Phantom } 4 \text { Pro Plus, GIS } \\
\text { (ArcGIS) }\end{array}$ & Greece & [28] \\
\hline & Mapping old hiking trails & DJI Mavic 2 Pro, GIS & China & {$[231,232]$} \\
\hline $\begin{array}{c}\text { Virtual } \\
\text { cinematography }\end{array}$ & $\begin{array}{l}\text { Modelling autonomous } \\
\text { driving and } \\
\text { human-robot interaction }\end{array}$ & DJI M210, GIS & $\mathrm{N} / \mathrm{A}$ & [233] \\
\hline Virtual reality & $\begin{array}{l}\text { 3D archaeological and } \\
\text { architectural } \\
\text { reconstruction }\end{array}$ & $\begin{array}{c}\text { UAV (3DR Pixhawk autopilot } \\
\text { system, DJI Phantom 4, DJI } \\
\text { Inspire 2), FARO Focus X330 } \\
\text { scanners, GIS (City Engine), } \\
\text { Google Earth }\end{array}$ & $\begin{array}{l}\text { Portugal, Greece, Italy, } \\
\text { Spain, Indonesia }\end{array}$ & {$[231,234-243]$} \\
\hline
\end{tabular}

Many of the possible uses of the two components are presented separately in the articles due to the high degree of focus of the subject. However, the significant number of articles that see this tandem as a solution for managing different territorial phenomena is an argument for several directions of the present study: (a) identification for each area revealed here, but also for others, of those utilities of UAS whose results can be capitalised on in the GIS environment; (b). identifying other possible applications in the digital context. The 454 studies that consider UAS and GIS as compatible technologies do not necessarily see their usefulness in a broader context [1], although connecting the two technologies can increase the rate of knowledge transfer to the public and private environment. This picture describing the usefulness of the technological tandem discussed must be promoted through activities to popularise science among the population in general and administration, in particular.

In addition, for the areas of applicability, it will be possible to create complex spatial databases that allow realtime digitisation and monitoring, without which we cannot offer a real digitalisation. Moreover, a digitalisation preceded by digitisation and continued by monitoring will generate a digital twin. The scalability of the results of UAS-GIS collaboration is emphasised by the diversity of current applicability and by the expected technical progress. Significant results can be obtained through simultaneous bottom-up and top-down reactions from all stakeholders.

The main findings and further recommendations associated with the use of UAS and GIS technology are also provided in Table 5.

Table 5. Main findings and further recommendations of the investigated scientific publications (2016-2021).

\begin{tabular}{|c|c|c|c|c|}
\hline $\begin{array}{l}\text { Application } \\
\text { Fields }\end{array}$ & Specific Contents & $\begin{array}{l}\text { Current Findings of UAV and GIS } \\
\text { Technologies }\end{array}$ & Further Investigations & References \\
\hline $\begin{array}{c}\text { Cultural } \\
\text { heritage } \\
\text { preservation }\end{array}$ & $\begin{array}{l}\text { 3D archaeological } \\
\text { or architectural } \\
\text { reconstruction }\end{array}$ & $\begin{array}{l}\text { The use of UAV and GNSS technologies in field } \\
\text { survey and the construction of high-resolution } \\
\text { DEM allowed a more detailed study of the } \\
\text { fortified settlements territory and } \\
\text { defensive structures. } \\
\text { Combining laser scanner and drone } \\
\text { photogrammetric information provide } \\
\text { 3D models. }\end{array}$ & $\begin{array}{l}\text { Wider campaigns of } \\
\text { 3D models; } \\
\text { Performing } \\
\text { automated methods }\end{array}$ & {$[59,60]$} \\
\hline
\end{tabular}


Table 5. Cont.

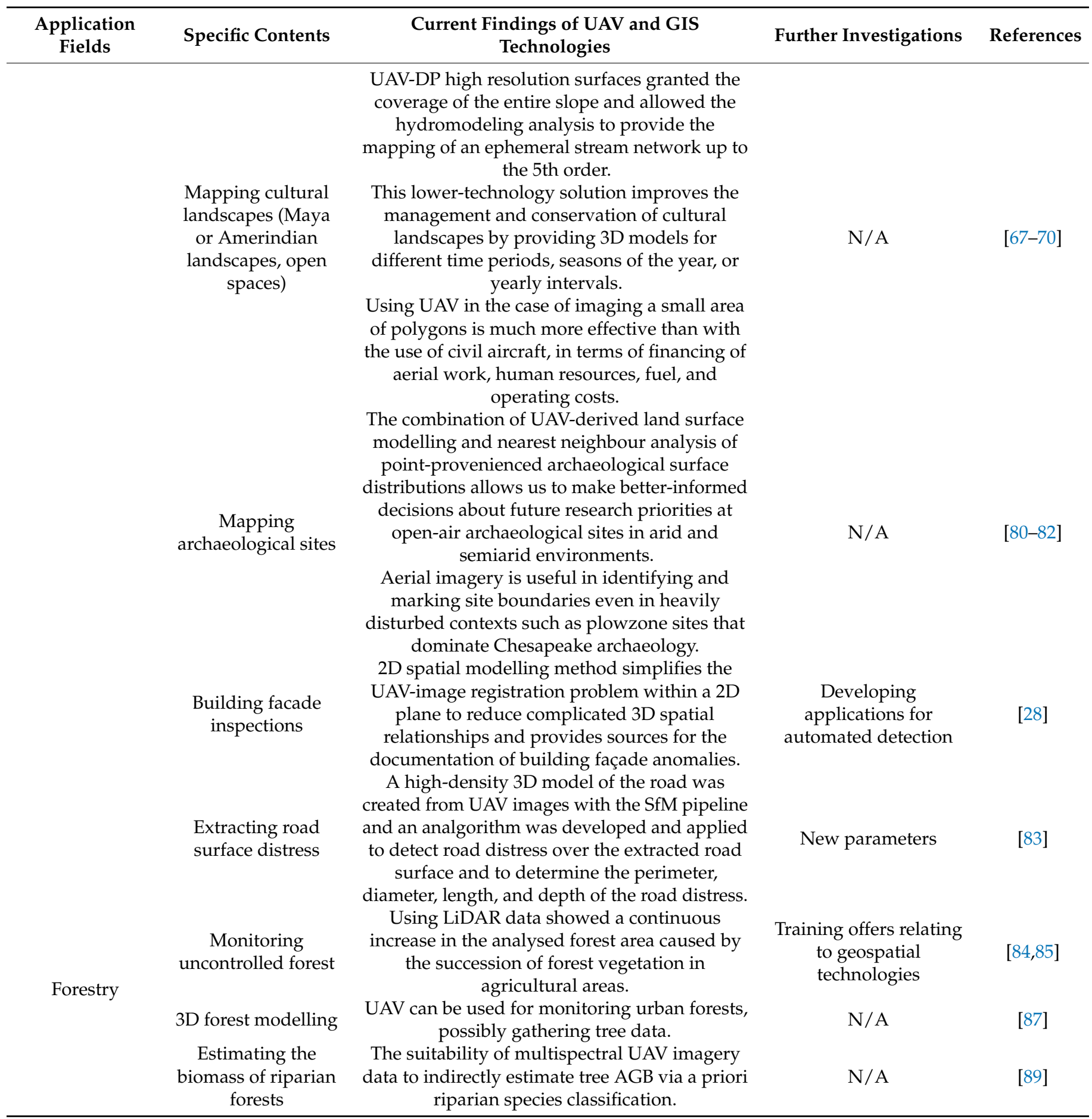


Table 5. Cont.

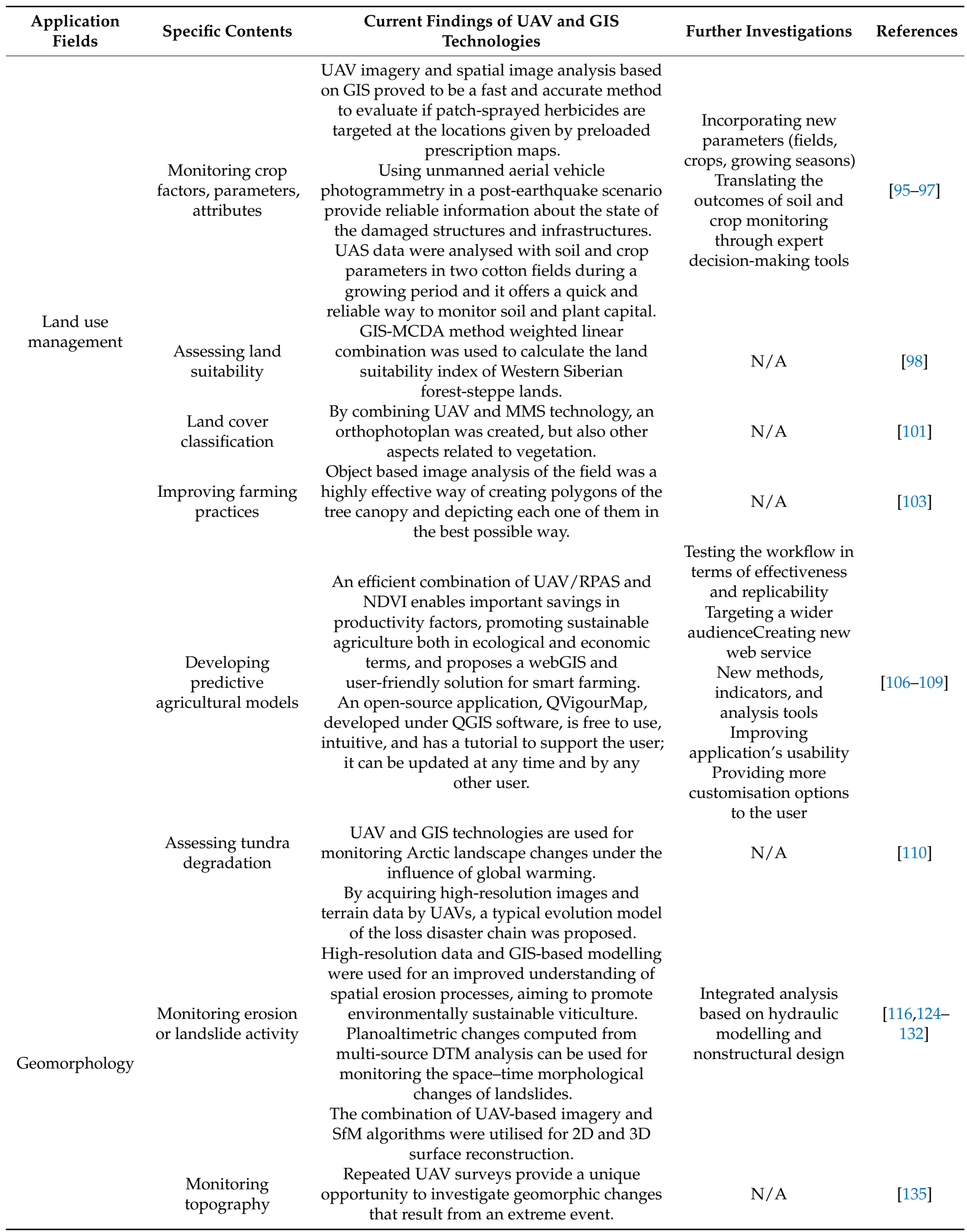


Table 5. Cont.

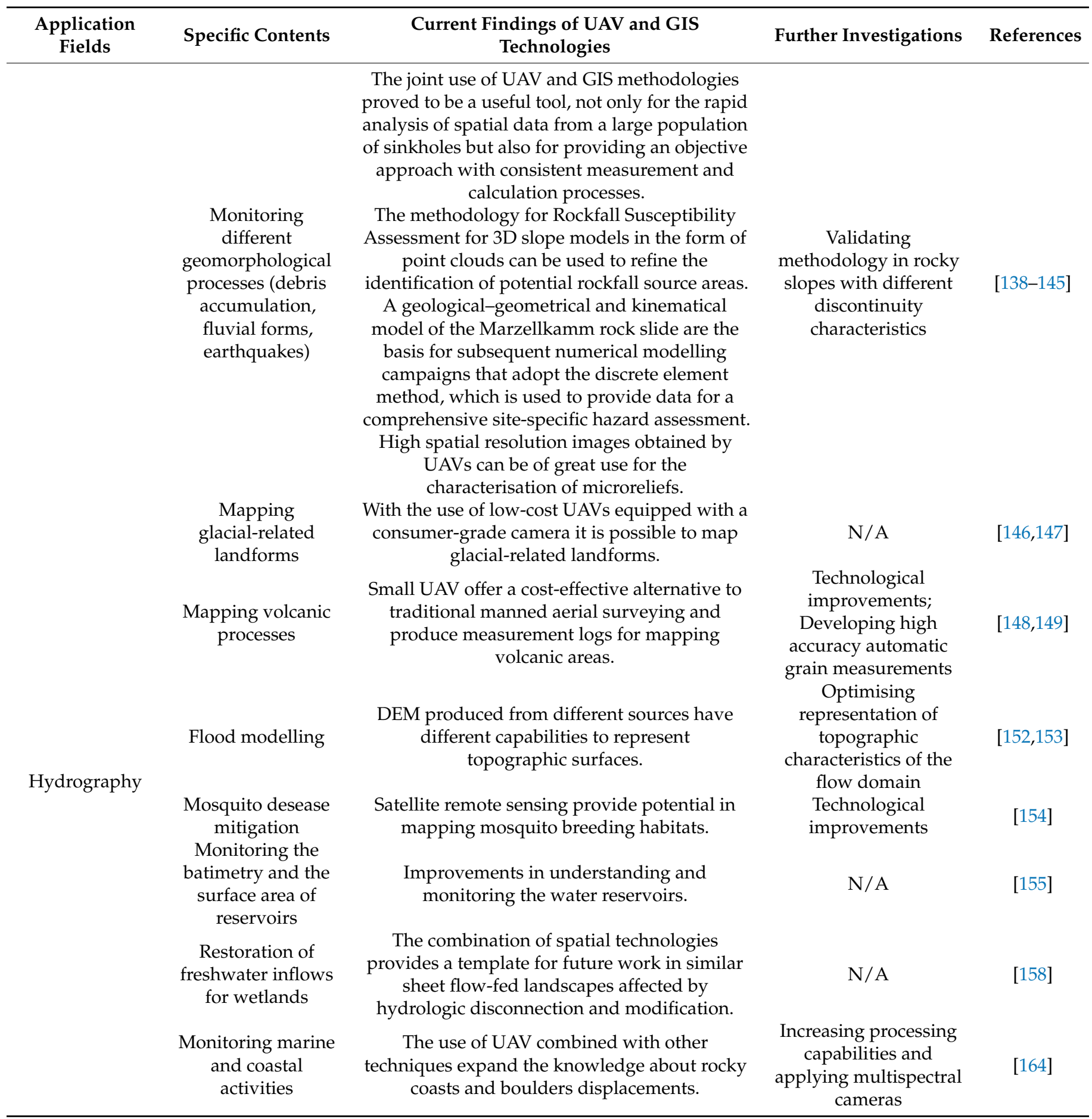


Table 5. Cont.

\begin{tabular}{|c|c|c|c|c|}
\hline $\begin{array}{l}\text { Application } \\
\text { Fields }\end{array}$ & Specific Contents & $\begin{array}{c}\text { Current Findings of UAV and GIS } \\
\text { Technologies }\end{array}$ & Further Investigations & References \\
\hline \multirow{6}{*}{ Engineering } & $\begin{array}{l}\text { Modelling different } \\
\text { infrastructure } \\
\text { works }\end{array}$ & $\begin{array}{l}\text { Data integrator allows user to automate the } \\
\text { updating infrastructure data. }\end{array}$ & $\mathrm{N} / \mathrm{A}$ & [167] \\
\hline & $\begin{array}{l}\text { Designing } \\
\text { emergency maps }\end{array}$ & $\begin{array}{l}\text { An automated building seismic damage } \\
\text { assessment method provide a useful tool for the } \\
\text { rapid regional seismic damage assessment of } \\
\text { buildings and assist the contingency response } \\
\text { and management. }\end{array}$ & $\mathrm{N} / \mathrm{A}$ & [172] \\
\hline & $\begin{array}{l}\text { Supervising road } \\
\text { and railway } \\
\text { maintenance works }\end{array}$ & $\begin{array}{l}\text { The usage of UAV is more efficient than the } \\
\text { conventional method; it saves cost, produces } \\
\text { accurate data, and verifies road maintenance } \\
\text { work systematically. }\end{array}$ & $\mathrm{N} / \mathrm{A}$ & [174] \\
\hline & $\begin{array}{l}\text { Estimating solar } \\
\text { energy potential }\end{array}$ & $\begin{array}{l}\text { The UAV-DSM method improves the estimates } \\
\text { of the radiation potential from a highly detailed } \\
\text { inexpensive 3D model, and these solar maps } \\
\text { become tools for planning disciplines. }\end{array}$ & $\begin{array}{l}\text { New parameters used } \\
\text { in estimating solar } \\
\text { energy potential }\end{array}$ & {$[176,177]$} \\
\hline & Mapping quarries & $\begin{array}{l}\text { The photogrammetric and GIS methods } \\
\text { provides an accurate assessment of } \\
\text { open-pit mining. } \\
\text { A UAS-based protocol allows fast monitoring } \\
\text { land restoration and synthesis of various } \\
\text { remote sensing applications into a single } \\
\text { workflow in order to obtain } \\
\text { cartographic products. }\end{array}$ & $\begin{array}{l}\text { Obtaining new } \\
\text { products like soil losses } \\
\text { by erosion or } \\
\text { vegetation change } \\
\text { maps }\end{array}$ & {$[179,180]$} \\
\hline & Cadaster mapping & $\begin{array}{l}\text { A semi-automated technique reduces manual } \\
\text { efforts and human interventions, and there is a } \\
\text { substantial reduction in time as there is a } \\
\text { limited digitisation process. }\end{array}$ & $\begin{array}{l}\text { Detecting segment } \\
\text { quality parameters }\end{array}$ & [182] \\
\hline \multirow[t]{3}{*}{ Medicine } & $\begin{array}{l}\text { Testing } \\
\text { high-incidence } \\
\text { areas }\end{array}$ & $\begin{array}{l}\text { Small number of drone systems increase } \\
\text { national coverage of OHCA substantially. }\end{array}$ & $\begin{array}{l}\text { Prospective real-life } \\
\text { studies }\end{array}$ & [183] \\
\hline & $\begin{array}{l}\text { Testing medical } \\
\text { drones for } \\
\text { emergency } \\
\text { purposes }\end{array}$ & $\begin{array}{c}\text { Identification of possible drone network } \\
\text { configurations that can reduce life-saving } \\
\text { equipment travel times for victims of } \\
\text { cardiac arrest. }\end{array}$ & $\begin{array}{l}\text { Legal and technical } \\
\text { improvements }\end{array}$ & [184-186] \\
\hline & $\begin{array}{l}\text { Monitoring coastal } \\
\text { landscapes }\end{array}$ & $\begin{array}{l}\text { Improvements of the accuracy of raster map for } \\
\text { monitoring inaccesible coastal areas. } \\
\text { UAV is an affordable and fast survey technique } \\
\text { that can rapidly increase the number of studies } \\
\text { on cliff habitats and improve ecological } \\
\text { knowledge on their plant species } \\
\text { and communities. }\end{array}$ & $\begin{array}{l}\text { Improving sensor and } \\
\text { drone technology }\end{array}$ & {$[187,189]$} \\
\hline \multirow[t]{2}{*}{$\begin{array}{l}\text { Nature and } \\
\text { eco-friendly } \\
\text { practices }\end{array}$} & $\begin{array}{l}\text { Detecting invasive } \\
\text { species }\end{array}$ & $\begin{array}{l}\text { Use of a multidisciplinary methodology to } \\
\text { quantitatively evaluate the role of plant species } \\
\text { in ecosystems, including invasive species } \\
\text { (density, clustering, and spread). } \\
\text { UAV low-altitude remote sensing allows } \\
\text { monitoring without destroying vegetation } \\
\text { because of its noncontact characteristic. }\end{array}$ & $\begin{array}{l}\text { Improving the } \\
\text { efficiency and } \\
\text { scalability of the image } \\
\text { analysis }\end{array}$ & [190-192] \\
\hline & $\begin{array}{l}\text { Monitoring and } \\
\text { modelling } \\
\text { environmental } \\
\text { contamination } \\
\text { (landfills, pollution } \\
\text { sources) }\end{array}$ & $\begin{array}{l}\text { Use of remote sensing techniques shows the } \\
\text { different spatial scales of high risk areas. } \\
\text { Drone monitoring has the potential to expand } \\
\text { spatial coverage to larger areas, monitor fragile } \\
\text { or inaccessible sites, and provide maps of litter } \\
\text { abundance and distribution. }\end{array}$ & $\begin{array}{l}\text { Testing new methods } \\
\text { for litter detection and } \\
\text { classification }\end{array}$ & $\begin{array}{l}{[195,196,} \\
198-200]\end{array}$ \\
\hline
\end{tabular}


Table 5. Cont.

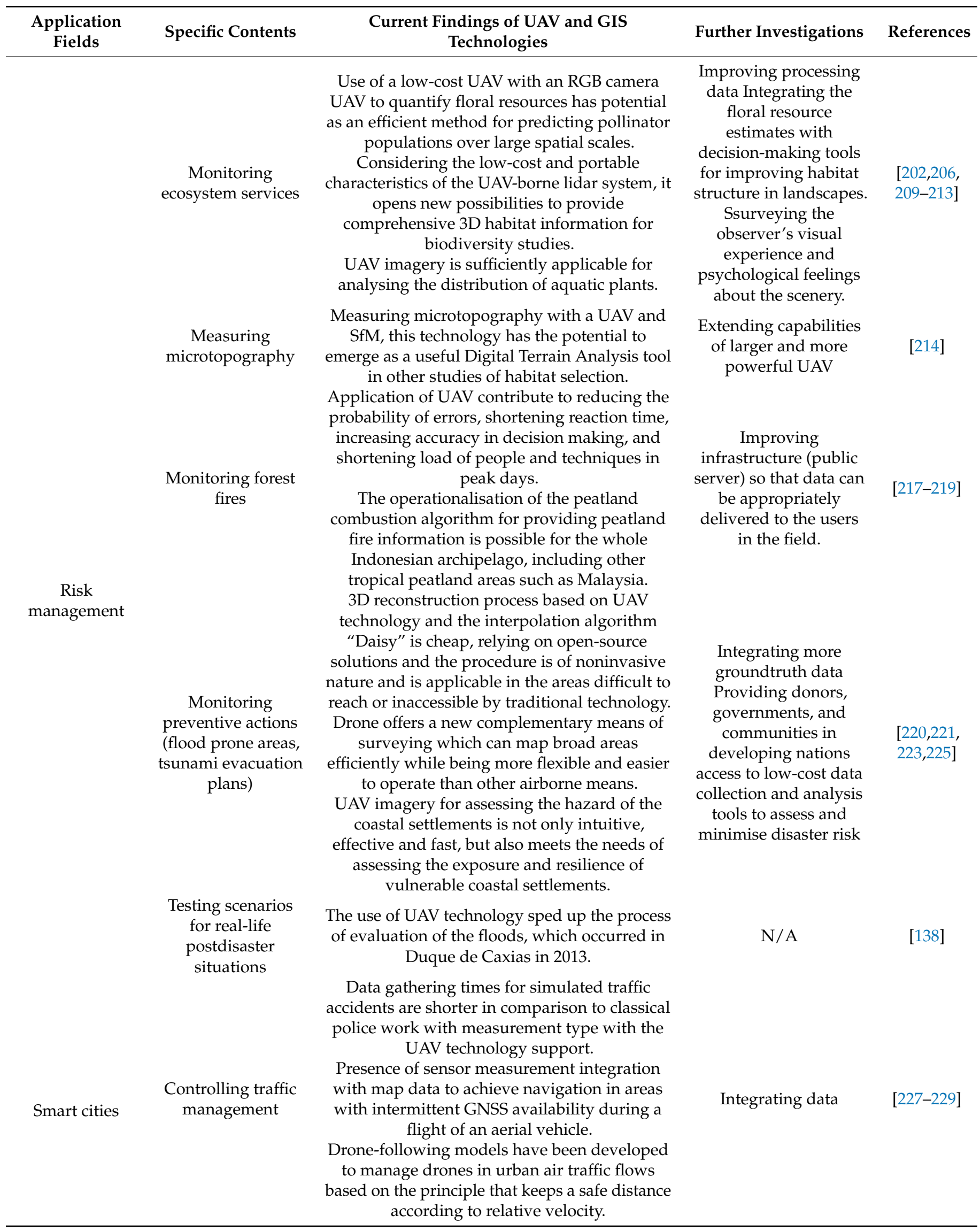


Table 5. Cont.

\begin{tabular}{|c|c|c|c|c|}
\hline $\begin{array}{l}\text { Application } \\
\text { Fields }\end{array}$ & Specific Contents & $\begin{array}{l}\text { Current Findings of UAV and GIS } \\
\text { Technologies }\end{array}$ & Further Investigations & References \\
\hline \multirow{4}{*}{ Tourism } & $\begin{array}{l}\text { Measuring } \\
\text { unauthorised } \\
\text { buildings }\end{array}$ & $\begin{array}{l}\text { After computer-automated processing, new } \\
\text { DSM data were obtained from elevation } \\
\text { differences in two-stage images and illegal } \\
\text { buildings could be identified. }\end{array}$ & $\mathrm{N} / \mathrm{A}$ & [230] \\
\hline & $\begin{array}{l}\text { Examining the } \\
\text { profile of UAV } \\
\text { photographers }\end{array}$ & $\begin{array}{l}\text { Investigating the photography behaviour and } \\
\text { preferences of emerging tourist groups by } \\
\text { introducing AI computing methods }\end{array}$ & $\begin{array}{c}\text { Qualitative } \\
\text { analyseswith UAV } \\
\text { photography tourists }\end{array}$ & [28] \\
\hline & $\begin{array}{l}\text { Creating touristic } \\
\text { story maps }\end{array}$ & $\begin{array}{l}\text { Creation of a web map, while providing } \\
\text { information to a broad audience. }\end{array}$ & $\mathrm{N} / \mathrm{A}$ & [231] \\
\hline & $\begin{array}{l}\text { Mapping old } \\
\text { hiking trails }\end{array}$ & $\begin{array}{c}\text { Developing a methodology to assess the safety } \\
\text { and suitability of an old close-downed forest } \\
\text { trail as an evocation to reopen it as a } \\
\text { hiking trail. }\end{array}$ & $\mathrm{N} / \mathrm{A}$ & [233] \\
\hline Virtual reality & $\begin{array}{l}\text { 3D archaeological } \\
\text { and architectural } \\
\text { reconstruction }\end{array}$ & $\begin{array}{l}\text { The use of advanced data acquisition and } \\
\text { analysis techniques offers considerable promise } \\
\text { in assisting the reconstruction of past } \\
\text { landscapes. } \\
\text { The generalised models and test datasets } \\
\text { construct individual image representations of } \\
\text { the depth and color of roof shapes. } \\
\text { Immersive data visualisation of the geospatial } \\
\text { GIS plant data may be rendered in a game } \\
\text { engine with high information fidelity to achieve } \\
\text { sensory accuracy. }\end{array}$ & $\begin{array}{l}\text { Integrating image } \\
\text { processing and } \\
\text { machine learning } \\
\text { approaches. } \\
\text { Introducing new cost } \\
\text { functions that penalise } \\
\text { inter-drone collisions } \\
\text { Introducing slight } \\
\text { modification in the } \\
\text { definition of artistic } \\
\text { parameters that define } \\
\text { the desired artistic shot } \\
\text { for our motion planner. } \\
\text { Creating volumetric } \\
\text { reconstruction of } \\
\text { dynamic scenes in } \\
\text { natural environments } \\
\text { in real-life conditions. } \\
\text { Learning the artistic } \\
\text { reasoning behind } \\
\text { human choices. } \\
\text { New algorithms to } \\
\text { simulate the } \\
\text { natural world }\end{array}$ & $\begin{array}{l}{[231,234-} \\
243]\end{array}$ \\
\hline
\end{tabular}

Aside from the further recommendations listed (Table 5), such as technical improvements, testing new parameters, indicators, algorithms, or methods in order to increase data accuracy, integrating different kind of data, we highlight the following features:

- promoting remote sensing study for crossdisciplinary research through new curricula, education programs, and inclusion in projects which will increase the responsibility of local communities for their natural environment [212,228];

- reducing the time required for the decision-making process and for preparation of the response operation achieved by the adoption of UAVs and GIS technologies [138];

- geospatial technologies support decision makers in order to implement a "culture of prevention" instead of a "culture of reaction" [160].

If the combined usage of the two technologies (UAV and GIS) has become more frequent over in recent years (2019), we can currently notice a trend of the research fields towards the management of some phenomena and 3D modelling of some spatial objects (Figure 6). 


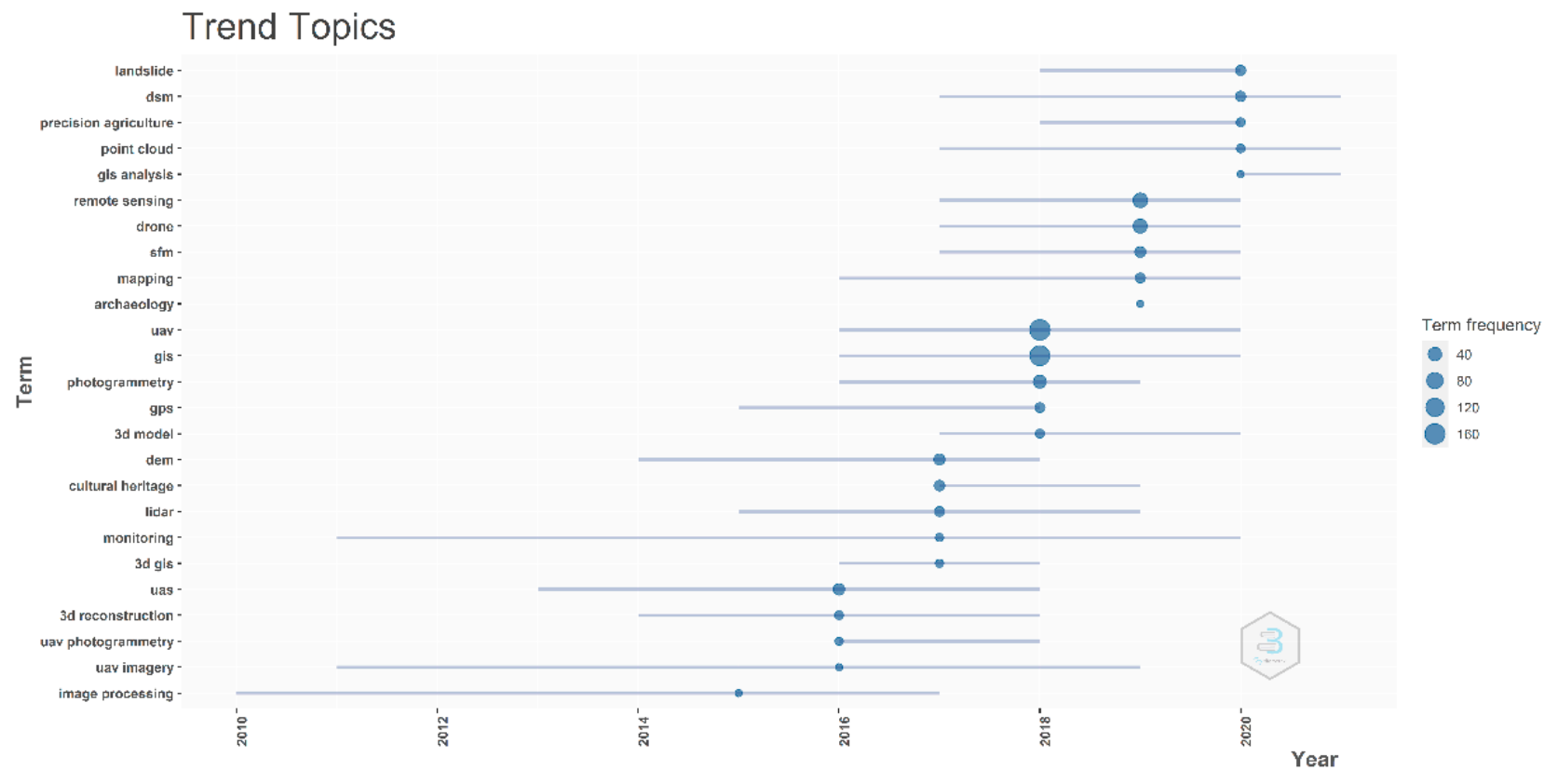

Figure 6. The evolution trend of the investigated research topics.

Among the vulnerabilities associated with DEG we mention: (a) adaptation of organisations, (b) information overload, and (c) data protection.

(a) In the context of the need identified by the United States Navy, in 2002: “ [ . . ] We need an organization that is very adaptive, that is very agile and is quick. Instead of having cycles that take years, we need cycles that take months because the threat changes [...]". The government sector includes obvious changes of organisations and organisational culture. Another common problem of the modern administration, regardless of the level, is not as much the increase in the costs related to the employees' wages, but the artificial development by some of the employees of some "boutique-bureaucracies" and the fragmentation of the decision-making process [2].

(b) The sudden transition from a quasi-lack of information to data overload, amplified especially by social media, accelerates the need for data and information that are scientifically validated. A paradox is highlighted in the context of Big Data's existence, which is considered to be able to solve the lack of data problem in the digital era [5]. Data warehousing sounds simple, but in the context of most of the national taxation, social security, immigration, and defence systems, especially in developed countries, it needs further development, with radical implications. The warehousing manner must activate the anticipation of the citizens' needs [2,4], including among other aspects, real-time government data-pooling by means of big data, from the local to regional level, open book government and citizen surveillance, open data initiatives, government cloud, etc. [1].

(c) The transition towards an open government will not be possible without an efficient protection of data and a free regime of the information for citizens [2]. With digitalisation, the individual will have more power to influence the policies of administration, the entrepreneurs will be able to manage business by avoiding excessive bureaucracy, and governments will be able to take more efficient measures in various sectors (public health, climate, and traffic). There is a risk deriving from this that government services remain inefficient [5].

\section{Conclusions}

Despite some uncertainties and alternatives, DEG continues to remain unique. It keeps the promise of a possible transition towards a more integrated administration, whose organisational operations are visible in detail both for the staff operating in the public domain, and for the citizens and organisations of civil society. Changes brought 
by DEG are closely correlated and will be strictly carried out in parallel with the increase in autonomous capacities of the citizens for the solving of social problems. The challenge for public managers will be to help the stakeholders of civil society [1]. DEG provides the theoretical and practical means for economies to shift from extractive economies into inclusive economies [244]. This statement is valid also for institutions, the result being the increase in their innovation capacity [5] because the digital infrastructure alone is not sufficient. Equally important are the digital skills that enable the use of digitalisation advantages [49].

Future research may focus on the ways to involve UAS and GIS users in the creation of digital twin models or the encouragement of direct democracy, an attempt to return to Athenian democracy, but by means of the current digital tools.

Author Contributions: G.-G.H., A.-M.P. and A.-C.M.-P.: Conceptualization, data collection, formal analysis, methodology, writing-original draft. G.-G.H.: funding acquisition. T.S.: data collection, visualization. All authors have read and agreed to the published version of the manuscript.

Funding: This research was funded by Babeș-Bolyai University, grant number GTC-31373/2020.

Institutional Review Board Statement: Not applicable.

Informed Consent Statement: Not applicable.

Data Availability Statement: Not applicable.

Acknowledgments: The authors express their gratitude for the anonymous referee for their helpful comments that help them to improve the quality of the manuscript.

Conflicts of Interest: The authors declare no conflict of interest.

\section{References}

1. Margetts, H.; Dunleavy, P. The second wave of digital-era governance: A quasi-paradigm for government on the Web. Phil. Trans. R. Soc. 2013, 371, 20120382. [CrossRef]

2. Dunleavy, P.; Margetts, H.; Boston, S.; Tinkler, J. New Public Management Is Dead-Lond Live Digital-Era Governance. J. Public Adm. Res. Theory 2005, 16, 467-497. [CrossRef]

3. Adegboyega, O.; Fatemeh, A.Z.; Mellouli, S. A Realist Perspective on AI era Public Management: An Analysis of Mechanisms, Outcomes and Challenges of AI Solutions in the Public Sector. In Proceedings of the 20th Annual International Conference on Digital Government Research (dg.o 2019), Dubai, United Arab Emirates, 18-20 June 2019; ACM: New York, NY, USA, $2019 ;$ p. 12. [CrossRef]

4. Kosenkov, A.; Pappel, I.; Draheim, D. On Existing Trends towards Creation of a Holistic Socio-technical Approach to e-Governance. In Proceedings of the 12th International Conference on Theory and Practice of Electronic Governance (ICEGOV2019), Melbourne, Australia, 3-5 April 2019. [CrossRef]

5. Erkut, B. From Digital Government to Digital Governance: Are We There Yet? Sustainability 2020, 12, 860. [CrossRef]

6. James, D.; Snider, C.; Nassehi, A.; Yon, J.; Hicks, B. Characterising the Digital Twin: A systematic literature review. CIRP J. Manuf. Sci. Technol. 2020, 29, 36-52. [CrossRef]

7. Larsson, A.; Teigland, R. An introduction to digital welfare: A way forward? In Digital Transformation and Public Services: Societal Impacts in Sweden and Beyond; Larsson, A., Teigland, R., Eds.; Routledge: Oxon, UK, 2020; pp. 1-11. Available online: https: / / ssrn.com/abstract=3502524 (accessed on 5 September 2021).

8. Bloomberg, J. Digitization, Digitalization, and Digital Transformation: Confuse Them at Your Peril. [online] Forbes. 2018. Available online: www.forbes.com/sites/jasonbloomberg/2018/04/29/digitization-digitalization-and-digital-transformationconfuse-them-at-your-peril (accessed on 7 September 2021).

9. Young, M.M. Implementation of Digital-Era Governance: The Case of Open Data in U.S. Cities. Public Adm. Rev. 2020, 80, 305-315. [CrossRef]

10. National Institute of Standards and Technology Special Publication 1011. Autonomy Levels for Unmanned Systems (ALFUS) Framework, Volume I: Terminology, Version 1.1. September 2004. Available online: https://www.nist.gov/system/files/ documents/el/isd/ks/NISTSP_1011_ver_1-1.pdf (accessed on 16 July 2021).

11. Greenwood, W.W.; Lynch, J.P.; Zekkos, D. Applications of UAVs in Civil Infrastructure. J. Infrastruct. Syst. 2019, $25,04019002$. [CrossRef]

12. Midrack, R.L. What Is a Third-Party App? You Use These Apps on Your Smartphone and Tablet All the Time. [online] Lifewere. 2020. Available online: www.lifewire.com/what-is-a-third-party-app-4154068 (accessed on 14 July 2021). 
13. Electronics Maker. Unmanned Vehicles-No Pilot/Driver on Board. 2014. Available online: https://electronicsmaker.com/ unmanned-vehicles-no-pilotdriver-on-board\#: \{\}:text=An\%20unmanned $\% 20$ vehicle $\% 20 \mathrm{is} \% 20$ the,including $\% 20$ reconnaissance $\%$ 20and\%20attack\%20roles (accessed on 16 July 2021).

14. Deliry, S.I.; Avdan, U. Accuracy of Unmanned Aerial Systems Photogrammetry and Structure from Motion in Surveying and Mapping. J. Indian Soc. Remote Sens. 2021, 49, 1997-2017. [CrossRef]

15. Balestrieri, E.; Daponte, P.; De Vito, L.; Lamonaca, F. Sensors and Measurements for Unmanned Systems: An Overview. Sensors 2021, 21, 1518. [CrossRef]

16. Yahuza, M.; Idris, M.Y.I.; Ahmedi, I.B.; Wahab, A.W.A.; Nandy, T.; Noor, N.M.; Bala, A. Internet of Drones Security and Privacy Issues: Taxonomy and Open Challenges. IEEE Access 2021, 9, 57243-57270. [CrossRef]

17. Merkert, R.; Bushell, J. Managing the drone revolution: A systematic literature review into the current use of airborne drones and future strategic directions for their effective control. J. Air Transp. Manag. 2020, 89, 101929. [CrossRef]

18. Qadir, Z.; Ullah, F.; Munawar, H.S.; Al-Turjman, F. Addressing disasters in smart cities through UAVs path planning and 5G communications: A systematic review. Comput. Commun. 2021, 168, 114-135. [CrossRef]

19. Mohamed, N.; Al-Jaroodi, J.; Jawhar, I.; Idries, A.; Mohammed, F. Unmanned aerial vehicles applications in future smart cities. Technol. Forecast. Soc. Chang. 2020, 153, 119293. [CrossRef]

20. Pavan Kumar, B.N.; Ashok Kumar, P.; Chethana, B.; Young Ho, C. On-Site 4-in-1 Alignment: Visualization and Interactive CAD Model Retrofitting Using UAV, LiDAR's Point Cloud Data, and Video. Sensors 2019, 19, 3908. [CrossRef]

21. Pavan Kumar, B.N.; Adithya, B.; Ashok Kumar, P.; Chethana, B.; Young Ho, C. GazeGuide: An Eye-Gaze-Guided Active Immersive UAV Camera. Appl. Sci. 2020, 10, 1668. [CrossRef]

22. Visvizi, A.; Lytras, M.D. It's Not a Fad: Smart Cities and Smart Villages Research in European and Global Contexts. Sustainability 2018, 10, 2727. [CrossRef]

23. Alsamhi, S.H.; Afghah, F.; Sahal, R.; Hawbani, A.; Al-qaness, M.A.A.; Lee, B.; Guizan, M. Green IoT using UAVs in B5G Networks: A Review of Applications and Strategies. Ad Hoc. Netw. 2021, 17, 102505. [CrossRef]

24. Liu, Y.; Dai, H.-N.; Wang, Q.; Shkla, M.K.; Imram, M. Unmanned aerial vehicle for internet of everything: Opportunities and challenges. Comput. Commun. 2020, 155, 66-83. [CrossRef]

25. Imoize, A.L.; Adedeji, O.; Tandiya, N.; Shetty, S. 6G Enabled Smart Infrastructure for Sustainable Society: Opportunities, Challenges, and Research Roadmap. Sensors 2021, 21, 1709. [CrossRef] [PubMed]

26. Sah, B.; Gupta, R.; Bani-Hani, D. Analysis of barriers to implement drone logistics. Int. J. Logist. Res. Appl. 2020, 1-20. [CrossRef]

27. Xu, C.; Liao, X.; Tan, J.; Ye, H.; Lu, H. Recent Research Progress of Unmanned Aerial Vehicle Regulation Policies and Technologies in Urban Low Altitude. IEEE Access 2020, 8, 74175-74194. [CrossRef]

28. Chen, G. GIS method and its application for harmonious evaluation of urban construction land and geological environment. Arab. J. Geosci. 2019, 12, 600. [CrossRef]

29. Liu, Z.; Cheng, L. Review of GIS Technology and Its Applications in Different Areas. IOP Conf. Ser. Mater. Sci. Eng. 2020, 735, 012066. [CrossRef]

30. Usmani, R.S.; Hashem, I.A.; Pillai, T.R.; Saeed, A.; Abdullahi, A.M. Geographic Information System and Big Spatial Data: A Review and Challenges. Int. J. Enterp. Inf. Syst. (IJEIS) 2020, 16, 101-145. [CrossRef]

31. de Queiroz, A.P. Spatial analysis: A bibliometric approach (1950-2019). Earth Sci. Inform. 2021, 14, 277-289. [CrossRef]

32. Jelokhani-Niaraki, M. Collaborative spatial multicriteria evaluation: A review and directions for future research. Int. J. Geogr. Inf. Sci. 2021, 35, 9-42. [CrossRef]

33. Murray, A.T. Contemporary optimization application through geographic information systems. Omega 2021, 99, 102176. [CrossRef]

34. Scheider, S.; Nyamsuren, E.; Kruiger, H.; Xu, H. Geoanalytical question-answering with GIS. Int. J. Digit. Earth 2021, 14, 1-14. [CrossRef]

35. Rowland, A.; Folmer, E.; Beek, W. Towards Self-Service GIS-Combining the Best of the Semantic Web and Web GIS. ISPRS Int. J. Geo-Inf. 2020, 9, 753. [CrossRef]

36. Fernandez, F.; Sanchez, A.; Velez, J.F.; Moreno, B. The Augmented Space of a Smart City. In Proceedings of the 2020 International Conference on Systems, Signals and Image Processing (IWSSIP), Niteroi, Brazil, 1-3 July 2020; pp. 465-470. [CrossRef]

37. Kurowska, K.; Marks-Bielska, R.; Bielski, S.; Aleknavičius, A.; Kowalczyk, C. Geographic Information Systems and the Sustainable Development of Rural Areas. Land 2021, 10, 6. [CrossRef]

38. Tripathi, A.K.; Agrawal, S.; Gupta, R.D. Cloud enabled SDI architecture: A review. Earth Sci. Inform. 2020, 13, 211-231. [CrossRef]

39. Polat, Z.A. Evolution and future trends in global research on cadastre: A bibliometric analysis. GeoJournal 2019, 84, 1121-1134. [CrossRef]

40. Ioannidis, C.; Potsiou, C.; Soile, S.; Verykokou, S.; Mourafetis, G.; Doulamis, N. Technical aspects for the creation of a MultiDimensional Land Information System. Int. Arch. Photogramm. Remote Sens. Spat. Inf. Sci. 2016, XLI-B2, 115-122. [CrossRef]

41. Wang, H.; Pan, Y.; Luo, X. Integration of BIM and GIS in sustainable built environment: A review and bibliometric analysis. Autom. Constr. 2019, 103, 41-52. [CrossRef]

42. Karimi, S.; Iordanova, I. Integration of BIM and GIS for Construction Automation, a Systematic Literature Revie (SLR) Combining Bibliometric and Qualitative Analysis. Arch. Comput. Methods Eng. 2021, 1-22. [CrossRef]

43. Khashoggi, B.F.; Murad, A. Issues of Healthcare Planning and GIS: A Review. ISPRS Int. J. Geo-Inf. 2020, 9, 352. [CrossRef] 
44. Saran, S.; Singh, P.; Kumar, V.; Chauhan, P. Review of Geospatial Technology for Infectious Disease Surveillance: Use Case on COVID-19. J. Indian Soc. Remote Sens. 2020, 48, 1121-1138. [CrossRef]

45. Asgari, M. A critical review on scale concept in GIS-based watershed management studies. Spat. Inf. Res. 2021, 29, 417-425. [CrossRef]

46. Sarker, M.N.I.; Peng, Y.; Yiran, C. Disaster resilience through big data: Way to environmental sustainability. Int. J. Disaster Risk Reduct. 2020, 51, 101769. [CrossRef]

47. Arvidsson, B.; Johansson, J.; Guldåker, N. Critical infrastructure, geographical information science and risk governance: A systematic cross-field review. Reliab. Eng. Syst. Saf. 2021, 213, 107741. [CrossRef]

48. Borrelli, P.; Alewell, C.; Alvarez, P.; Anache, J.A.A.; Baartman, J.; Ballabio, C.; Bezak, N.; Biddoccu, M.; Cerdà, A.; Chalise, D.; et al. Soil erosion modelling: A global review and statistical analysis. Sci. Total. Environ. 2021, 780, 146494. [CrossRef]

49. Stojanova, S.; Lentini, G.; Niederer, P.; Egger, T.; Cvar, N.; Kos, A.; Stojmenova Duh, E. Smart Villages Policies: Past, Present and Future. Sustainability 2021, 13, 1663. [CrossRef]

50. Earley-Spadoni, T. Spatial History, deep mapping and digital storytelling: Archaeology's future imagined through an engagement with the Digital Humanities. J. Archaeol. Sci. 2017, 84, 95-102. [CrossRef]

51. Janssen, P.; Loh, P.; Raonic, A.; Schnabel, M.A. Protocols, Flows and Glitches. In Proceedings of the 22nd International Conference of the Association for Computer-Aided Architectural Design Research in Asia (CAADRIA), Suzhou, China, 5-8 April 2017; pp. 663-673.

52. Marques, L.; Tenedório, J.; Burns, M.; Româo, T.; Birra, F.; Marques, J.; Pires, A. Cultural heritage 3D modelling and visualisation within an augmented reality environment, based on geographic information technologies and mobile platforms. ACE Archit. City Environ. 2017, 11, 117-136.

53. Gennaro, A.; Mangiameli, M.; Muscato, G.; Mussumeci, G.; Sgarlata, M. Geomatic techniques for surveying and mapping an archaeological site. In Proceedings of the Metrology for Archaeology and Cultural Heritage (MetroArchaeo), Cassino, Italy, 22-24 October 2018; pp. 277-281. [CrossRef]

54. Kreij, A.; Scriffignano, J.; Rosendahl, D.; Nagel, T.; Ulm, S. Aboriginal stone-walled intertidal fishtrap morphology, function and chronology investigated with high-resolution close-range Unmanned Aerial Vehicle photogrammetry. J. Archaeol. Sci. 2018, 96, 148-161. [CrossRef]

55. Malinverni, E.S.; Giuliano, A.A.; Mariano, F. 3D information management system for the conservation of an old deserted military site. In Proceedings of the 2018 Metrology for Archaeology and Cultural Heritage (MetroArchaeo), Cassino, Italy, 22-24 October 2018; pp. 188-192. [CrossRef]

56. Tache, A.; Sandu, I.; Popescu, O.; Petrisor, A. UAV Solutions for The Protection and Management of Cultural Heritage. Case Study: Halmyris Archaeological Site. Int. J. Conserv. Sci. 2018, 9, 795-804.

57. Nicu, I.C.; Usmanov, B.; Gainullin, I.; Galimova, M. Shoreline Dynamics and Evaluation of Cultural Heritage Sites on the Shores of Large Reservoirs: Kuibyshev Reservoir, Russian Federation. Water 2019, 11, 591. [CrossRef]

58. O'Driscoll, J. Picture Perfect: Using Drone Technology and Photogrammetry Techniques to Map the Western Stone Forts of Ireland. J. Field Archaeol. 2019, 44, 126-146. [CrossRef]

59. Gainullin, I.; Usmanov, B.; Gafurov, A. Study of fluvial processes impact on archaeological sites of the Volga Bulgaria period using remote sensing data. In Proceedings of the Eighth International Conference on Remote Sensing and Geoinformation of the Environment (RSCy 2020), Paphos, Cyprus, 26 August 2020; p. 1152409. [CrossRef]

60. Mohd Noor, N.; Ibrahim, I.; Abdullah, A.; Abdullah, A.A.A. Information Fusion for Cultural Heritage Three-Dimensional Modeling of Malay Cities. ISPRS Int. J. Geo-Inf. 2020, 9, 177. [CrossRef]

61. Sonnemann, T.F.; Ulloa Hung, J.; Hofman, C.L. Mapping Indigenous Settlement Topography in the Caribbean Using Drones. Remote Sens. 2016, 8, 791. [CrossRef]

62. Sabha, M.; Abu Daoud, J.J. Adaptive Camera Placement for Open Heritage Sites. In Proceedings of the International Conference on Future Networks and Distributed Systems (ICFNDS '17), New York, NY, USA, 19-20 July 2017; Association for Computing Machinery: New York, NY, USA, 2017; pp. 1-7. [CrossRef]

63. Vermeulen, F. Scanning and Visualization of Roman Adriatic Townscapes. In Proceedings of the Knowledge, Analysis and Innovative Methods for the Study and the Dissemination of Ancient Urban Areas. Proceedings of the KAINUA 2017 International Conference in Honour of Professor Giuseppe Sassatelli's 70th Birthday, Bologna, Italy, 18-21 April 2017; Garagnani, S., Gaucci, A., Eds.; All'Insegna del Giglio: Firenze, Italy, 2017; Volume 28, pp. 269-276.

64. Kullmann, K. Design with (human) nature: Recovering the creative instrumentality of social data in urban design. J. Urban Des. 2019, 24, 165-182. [CrossRef]

65. Spano, A.; Sammartano, G.; Calcagno Tunin, F.; Cerise, S.; Possi, G. GIS-based detection of terraced landscape heritage: Comparative tests using regional DEMs and UAV data. Appl. Geomat. 2018, 10, 77-97. [CrossRef]

66. Murtha, T.; Broadbent, E.; Golden, C.; Scherer, A.; Schroder, W.; Wilkinson, B.; Zambrano, A. Drone-Mounted Lidar Survey of Maya Settlement and Landscape. Lat. Am. Antiq. 2019, 30, 630-636. [CrossRef]

67. Frodella, W.; Elashvili, M.; Spizzichino, D.; Gigli, G.; Adikashvili, L.; Vacheishvili, N.; Kirkitadze, G.; Nadaraia, A.; Margottini, C.; Casagli, N. Combining InfraRed Thermography and UAV Digital Photogrammetry for the Protection and Conservation of Rupestrian Cultural Heritage Sites in Georgia: A Methodological Application. Remote Sens. 2020, 12, 892. [CrossRef] 
68. Herrero-Tejedor, T.R.; Arqués Soler, F.; López-Cuervo Medina, S.; de la O Cabrera, M.R.; Martín Romero, J.L. Documenting a cultural landscape using point-cloud 3d models obtained with geomatic integration techniques. The case of the El Encín atomic garden, Madrid (Spain). PLoS ONE 2020, 15, e0235169. [CrossRef]

69. Chromčák, J.; Bačová, D.; Pecho, P.; Seidlová, A. The Possibilities of Orthophotos Application for Calculation of Ecological Stability Coefficient Purposes. Sustainability 2021, 13, 3017. [CrossRef]

70. Uribe, P.; Angás, J.; Romeo, F.; Pérez-Cabello, F.; Santamaría, D. Mapping Ancient Battlefields in a multi-scalar approach combining Drone Imagery and Geophysical Surveys: The Roman siege of the oppidum of Cabezo de Alcalá (Azaila, Spain). J. Cult. Herit. 2021, 48, 11-23. [CrossRef]

71. Wernke, S.A.; Lauren, E.; Kohut, L.E.; Traslaviña, A. A GIS of affordances: Movement and visibility at a planned colonial town in highland Peru. J. Archaeol. Sci. 2017, 84, 22-39. [CrossRef]

72. Cantoro, G. Ground and aerial digital documentation of cultural heritage: Providing tools for 3D exploitation of archaeological data. ISPRS-Int. Arch. Photogramm. Remote Sens. Spat. Inf. Sci. 2017, 42, 141-145. [CrossRef]

73. Lasaponara, R.; Masini, N. Living in the Golden Age of Digital Archaeology. In Proceedings of the Computational Science and Its Applications-ICCSA 2016, Beijing, China, 4-7 July 2016; Gervasi, O., Murgante, B., Misra, S., Rocha, A.M.A.C., Torre, C.M., Taniar, D., Apduhan, B.O., Stankova, E., Wang, S., Eds.; Spring: Berlin/Heidelberg, Germany, 2016; Volume 9787. [CrossRef]

74. Parcero-Oubiña, C.; Fábrega-Álvarez, P.; Salazar, D.; Troncoso, A.; Hayashida, F.; Pino, M.; Borie, C.; Echenique, E. Ground to air and back again: Archaeological prospection to characterize prehispanic agricultural practices in the high-altitude Atacama (Chile). Quat. Int. 2017, 435, 98-113. [CrossRef]

75. Angelats, E.; Ontiveros, M.Á.C.; Florit, C.M. High resolution orthophotos and a digital surface model of the Roman city of Pollentia (Mallorca, Spain) using RPAS imagery, aerial images, and open data archives. In Proceedings of the 2018 Metrology for Archaeology and Cultural Heritage (MetroArchaeo), Cassino, Italy, 22-24 October 2018; pp. 178-182. [CrossRef]

76. Chelmus, A.; Radvan, R.; Angheluta, L. Aerial Investigations Corroboration for Archaeology and Monuments. In Proceedings of the 2018 11th International Conference on Developments in eSystems Engineering (DeSE), Cambridge, UK, 2-5 September 2018; pp. 113-116. [CrossRef]

77. Abate, N.; Lasaponara, R. Preventive Archaeology Based on Open Remote Sensing Data and Tools: The Cases of Sant'Arsenio (SA) and Foggia (FG), Italy. Sustainability 2019, 11, 4145. [CrossRef]

78. Susam, T. Topographical Analyses of Unmanned Aerial Vehicle-Based Very High-Resolution Digital Surface Models for Archaeological Sites. Teh. Vjesn.-Tech. Gaz. 2019, 26, 236-242.

79. Tapete, D. Earth Observation, Remote Sensing, and Geoscientific Ground Investigations for Archaeological and Heritage Research. Geosciences 2019, 9, 161. [CrossRef]

80. Ames, C.J.H.; Chambers, S.; Shaw, M.; Philips, N.; Jones, B.G.; Mackay, A. Evaluating erosional impacts on open-air archaeological sites along the Doring River, South Africa: Methods and implications for research prioritization. Archaeol. Anthropol. Sci. 2020, 12, 103. [CrossRef]

81. Gijanto, L. Interpreting West Ashcom: Drones, Artifacts, and Archives. Int. J. Histor. Archaeol. 2020, 24, 780-802. [CrossRef]

82. Senkal, E.; Kaplan, G.; Avdan, U. Accuracy assessment of digital surface models from unmanned aerial vehicles' imagery on archaeological sites. Int. J. Eng. Geosci. 2021, 6, 81-89.

83. Biçici, S.; Mustafa Zeybek, M. An approach for the automated extraction of road surface distress from a UAV-derived point cloud. Autom. Constr. 2021, 122, 103475. [CrossRef]

84. De Gouw, S.; Morgenroth, J.; Xu, C. An updated survey on the use of geospatial technologies in New Zealand's plantation forestry sector. N. Z. J. For. Sci. 2020, 50. [CrossRef]

85. Szostak, M. Automated Land Cover Change Detection and Forest Succession Monitoring Using LiDAR Point Clouds and GIS Analyses. Geosciences 2020, 10, 321. [CrossRef]

86. Panagiotidis, D.; Abdollahnejad, A.; Surový, P.; Chiteculo, V. Determining tree height and crown diameter from high-resolution UAV imagery. Int. J. Remote Sens. 2017, 38, 2392-2410. [CrossRef]

87. Isibue, E.W.; Pingel, T.J. Unmanned aerial vehicle based measurement of urban forests. Urban For. Urban Green. 2020, $48,126574$. [CrossRef]

88. Christiansen, M.P.; Laursen, M.; Jørgensen, R.N.; Skovsen, S.; Gislum, R. Designing and Testing a UAV Mapping System for Agricultural Field Surveying. Sensors 2017, 17, 2703. [CrossRef]

89. Fernandes, M.R.; Aguiar, F.C.; Martins, M.J.; Rico, N.; Ferreira, M.T.; Correia, A.C. Carbon Stock Estimations in a Mediterranean Riparian Forest: A Case Study Combining Field Data and UAV Imagery. Forests 2020, 11, 376. [CrossRef]

90. Stereńczak, K.; Mroczek, P.; Jastrzębowski, S.; Krok, G.; Lisanczuk, M.; Klisz, M.; Kantorowicz, W. UAV and GIS Based tool for collection and propagation of seeds material-First Results. Int. Arch. Photogramm. Remote Sens. Spat. Inf. Sci. 2016, 41, 663-667.

91. Zhang, H.M.; Yang, J.T.; Baartman, J.E.M.; Li, S.Q.; Jin, B.; Han, W.T. Quality of terrestrial data derived from UAV photogrammetry: A case study of Hetao irrigation district in northern China. Int. J. Agric. Biol. Eng. 2018, 11, 171-177. [CrossRef]

92. Fathelrahman, E.; Neumann, E.; Hussein, M.; IEEE, S.; Jalil, A.; Hassan, A.; Dirir, A.; Muhammad, S. Unmanned Arial Vehicle (UAV) Imagery and Manual Sampling for Parasitic Weed Recognition and Measurements. In Proceedings of the 2019 International Conference on Electrical and Computing Technologies and Applications (ICECTA), Ras Al Khaimah, United Arab Emirates, 19-21 November 2019; pp. 1-4. [CrossRef] 
93. Gábrlík, P.; Janata, P.; Žalud, L.; Harčarik, J. Towards Automatic UAS-Based Snow-Field Monitoring for Microclimate Research. Sensors 2019, 19, 1945. [CrossRef]

94. Wei-Ling, H.; Kuan-Tsung, C. Cross-estimation of Soil Moisture Using Thermal Infrared Images with Different Resolutions. Sens. Mater. 2019, 31, 387-398. [CrossRef]

95. Rasmussen, J.; Azim, S.; Nielsen, J.; Mikkelsen, B.F.; Hørfarter, R.; Christensen, S. A new method to estimate the spatial correlation between planned and actual patch spraying of herbicides. Precis. Agric. 2020, 21, 713-728. [CrossRef]

96. Zhang, R.; Li, H.; Duan, K.; You, S.; Liu, K.; Wang, F.; Hu, Y. Automatic Detection of Earthquake-Damaged Buildings by Integrating UAV Oblique Photography and Infrared Thermal Imaging. Remote Sens. 2020, 12, 2621. [CrossRef]

97. Papadopoulos, A.V.; Kalivas, D.P. Assessing Soil and Crop Characteristics at Sub-Field Level Using Unmanned Aerial System and Geospatial Analysis. Sustainability 2021, 13, 2855. [CrossRef]

98. Kalichkin, V.K.; Pavlova, A.I.; Logachova, O.M. GIS-based multi-criteria analysis of the suitability of Western Siberian foreststeppe lands. Ann. GIS 2021, 27, 225-237. [CrossRef]

99. Šedina, J.; Pavelka, K.; Raeva, P. UAV remote sensing capability for precision agriculture, forestry and small natural reservation monitoring. In Proceedings of the Hyperspectral Imaging Sensors: Innovative Applications and Sensor Standards, Anaheim, CA, USA, 9-13 April 2017; p. 102130. [CrossRef]

100. Al-Najjar, H.A.H.; Kalantar, B.; Pradhan, B.; Saeidi, V.; Halin, A.A.; Ueda, N.; Mansor, S. Land Cover Classification from fused DSM and UAV Images Using Convolutional Neural Networks. Remote Sens. 2019, 11, 1461. [CrossRef]

101. Simon, M.; Popescu, C.A.; Copăcean, L.; Cojocariu, L. Complex model based on UAV technology for investigating pastoral space. Present Environ. Sustain. Dev. 2020, 14. [CrossRef]

102. Alekseev, A.; Danilov, Y.; Nikiforov, A.; Guzuk, M.; Kireev, D. The use of unmanned aerial vehicle (UAV) for inventory and assessment of the experimental plantation in Lisino training and experimental forest of Saint-Petersburg State Forest Technical University. In Proceedings of the IOP Conference Series: Earth and Environmental Science, Volume 316, IV Scientific-Technical Conference “FORESTS OF RUSSIA: POLICY, INDUSTRY, SCIENCE AND EDUCATION”, St. Petersburg, Russia, 22-24 May 2019.

103. Stateras, D.; Kalivas, D. Assessment of Olive Tree Canopy Characteristics and Yield Forecast Model Using High Resolution UAV Imagery. Agriculture 2020, 10, 385. [CrossRef]

104. Papadopoulos, A.V.; Kalivas, D.; Theocharopoulos, S. Spatio-temporal monitoring of cotton cultivation using ground-based and airborne multispectral sensors in GIS environment. Environ. Monit. Assess 2017, 189, 323. [CrossRef]

105. Merchán-Benavides, S.; Lagos-Ortiz, K.; Rodríguez-Jarama, F.; Vera-Chica, R. Prediction of the Yield Per Hectare of the Crop of Chili Pepper (Capsicumchinense), by Means of a Simulation Model with GIS. A Case Study in Santo Domingo-San Jacinto Del Bua. In Proceedings of the Technologies and Innovation. CITI 2019. Communications in Computer and Information Science, Guayaquil, Ecuador, 2-5 December 2019; Valencia-García, R., Alcaraz-Mármol, G., Del Cioppo-Morstadt, J., Vera-Lucio, N., Bucaram-Leverone, M., Eds.; Springer: Cham, Switzerland, 2019; Volume 1124. [CrossRef]

106. Fukano, Y.; Guo, W.; Aoki, N.; Ootsuka, S.; Noshita, K.; Uchida, K.; Kato, Y.; Sasaki, K.; Kamikawa, S.; Kubota, H. GIS-Based Analysis for UAV-Supported Field Experiments Reveals Soybean Traits Associated With Rotational Benefit. Front. Plant Sci. 2021, 12, 637694. [CrossRef]

107. Loures, L.; Chamizo, A.; Ferreira, P.; Loures, A.; Castanho, R.; Panagopoulos, T. Assessing the Effectiveness of Precision Agriculture Management Systems in Mediterranean Small Farms. Sustainability 2020, 12, 3765. [CrossRef]

108. Belcore, E.; Angeli, S.; Colucci, E.; Musci, M.A.; Aicardi, I. Precision Agriculture Workflow, from Data Collection to Data Management Using FOSS Tools: An Application in Northern Italy Vineyard. ISPRS Int. J. Geo-Inf. 2021, 10, 236. [CrossRef]

109. Duarte, L.; Teodoro, A.C.; Sousa, J.J.; Pádua, L. QVigourMap: A GIS Open Source Application for the Creation of Canopy Vigour Maps. Agronomy 2021, 11, 952. [CrossRef]

110. Kartoziia, A. Assessment of the Ice Wedge Polygon Current State by Means of UAV Imagery Analysis (Samoylov Island, the Lena Delta). Remote Sens. 2019, 11, 1627. [CrossRef]

111. Al-Rawabdeh, A.; He, F.; Moussa, A.; El-Sheimy, N.; Habib, A. Using an Unmanned Aerial Vehicle-Based Digital Imaging System to Derive a 3D Point Cloud for Landslide Scarp Recognition. Remote Sens. 2016, 8, 95. [CrossRef]

112. Fernández, T.; Pérez, J.L.; Cardenal, J.; Gómez, J.M.; Colomo, C.; Delgado, J. Analysis of Landslide Evolution Affecting Olive Groves Using UAV and Photogrammetric Techniques. Remote Sens. 2016, 8, 837. [CrossRef]

113. Pirasteh, S.; Li, J. Landslides investigations from geoinformatics perspective: Quality, challenges, and recommendations. Geomat. Nat. Hazards Risk 2017, 8, 448-465. [CrossRef]

114. Fan, X.; Zhan, W.; Dong, X.; Westen, C.; Xu, Q.; Dai, L.; Yang, Q.; Huang, R.; Havenith, H.B. Analyzing successive landslide dam formation by different triggering mechanisms: The case of the Tangjiawan landslide, Sichuan, China. Eng. Geol. 2018, 243, 128-144. [CrossRef]

115. Borrelli, L.; Conforti, M.; Mercuri, M. LiDAR and UAV System Data to Analyse Recent Morphological Changes of a Small Drainage Basin. ISPRS Int. J. Geo-Inf. 2019, 8, 536. [CrossRef]

116. Godone, D.; Allasia, P.; Borrelli, L.; Gullà, G. UAV and Structure from Motion Approach to Monitor the Maierato Landslide Evolution. Remote Sens. 2020, 12, 1039. [CrossRef] 
117. Kosolapov, A.E.; Skripka, G.I.; Bespalova, L.A.; Ivlieva, O.V.; Filatov, A.A. Study of Morphological and Morphometric Characteristics of Tsimlyansk Reservoir Shores Using Unmanned Aerial Vehicles and GIS Technologies. Arid Ecosyst. 2018, 8, 184-189. [CrossRef]

118. Horacio, J.; Muñoz-Narciso, E.; Trenhaile, A.S.; Pérez-Alberti, A. Remote sensing monitoring of a coastal-valley earthflow in northwestern Galicia, Spain. Catena 2019, 178, 276-287. [CrossRef]

119. Báčová, M.; Krása, J.; Devátý, J.; Kavka, P. A GIS method for volumetric assessments of erosion rills from digital surface models. Eur. J. Remote Sens. 2019, 52, 96-107. [CrossRef]

120. Chen, X.; Li, G.; Yang, L.; Nie, Q.; Ye, X.; Liang, Y.; Xu, T. Profiling unmanned aerial vehicle photography tourists. Curr. Issues Tour. 2019, 23, 1705-1710. [CrossRef]

121. Chudý, F.; Slámová, M.; Tomaštík, J.; Prokešová, R.; Mokroš, M. Identification of Micro-Scale Landforms of Landslides Using Precise Digital Elevation Models. Geosciences 2019, 9, 117. [CrossRef]

122. Tavakkoli Piralilou, S.; Shahabi, H.; Jarihani, B.; Ghorbanzadeh, O.; Blaschke, T.; Gholamnia, K.; Meena, S.R.; Aryal, J. Landslide Detection Using Multi-Scale Image Segmentation and Different Machine Learning Models in the Higher Himalayas. Remote Sens. 2019, 11, 2575. [CrossRef]

123. Zhang, Y.; Zhao, Y.; Liu, B.; Wang, Z.; Zhang, S. Rill and gully erosion on unpaved roads under heavy rainfall in agricultural watersheds on China's Loess Plateau. Agric. Ecosyst. Environ. 2019, 284, 106580. [CrossRef]

124. Hu, S.; Qiu, H.; Wang, N.; Cui, Y.; Wang, J.; Wang, X.; Ma, S.; Yang, D.; Cao, M. The influence of loess cave development upon landslides and geomorphologic evolution: A case study from the northwest Loess Plateau, China. Geomorphology 2020, 359, 107167. [CrossRef]

125. Pijl, A.; Reuter, L.E.; Quarella, E.; Vogel, T.A.; Tarolli, P. GIS-based soil erosion modelling under various steep-slope vineyard practices. Catena 2020, 193, 104604. [CrossRef]

126. Williamson, J.; Nicu, I.C. Photogrammetric Measurement of Erosion at the Sabbath Point Beothuk Site in Central Newfoundland, Canada. Sustainability 2020, 12, 7555. [CrossRef]

127. Bilașco, Ș.; Roșca, S.; Vescan, I.; Fodorean, I.; Dohotar, V.; Sestras, P. A GIS-Based Spatial Analysis Model Approach for Identification of Optimal Hydrotechnical Solutions for Gully Erosion Stabilization. Case Study. Appl. Sci. 2021, $11,4847$. [CrossRef]

128. Conforti, M.; Mercuri, M.; Borrelli, L. Morphological Changes Detection of a Large Earthflow Using Archived Images, LiDARDerived DTM, and UAV-Based Remote Sensing. Remote Sens. 2021, 13, 120. [CrossRef]

129. Yang, D.; Qiu, H.; Hu, S.; Pei, Y.; Wang, X.; Du, C.; Long, Y.; Cao, M. Influence of successive landslides on topographic changes revealed by multitemporal high-resolution UAS-based DEM. Catena 2021, 202, 105229. [CrossRef]

130. Kyriou, A.; Kakavas, M.; Nikolakopoulos, K.; Koukouvelas, I.; Stefanopoulos, P.; Zygouri, V.; Tsigalidas, D. Landslide mapping and volume estimation using UAV-based point clouds, GIS and geophysical techniques. In Earth Resources and Environmental Remote Sensing/GIS Applications XI; International Society for Optics and Photonics: Bellingham, WA, USA; p. 115340. [CrossRef]

131. Kyriou, A.; Nikolakopoulos, K.; Koukouvelas, I.; Lampropoulou, P. Repeated UAV Campaigns, GNSS Measurements, GIS, and Petrographic Analyses for Landslide Mapping and Monitoring. Minerals 2021, 11, 300. [CrossRef]

132. Koutalakis, P.D.; Tzoraki, O.A.; Prazioutis, G.I.; Gkiatas, G.T.; Zaimes, G.N. Can Drones Map Earth Cracks? Landslide Measurements in North Greece Using UAV Photogrammetry for Nature-Based Solutions. Sustainability 2021, 13, 4697. [CrossRef]

133. Iizuka, K.; Itoh, M.; Shiodera, S.; Matsubara, T.; Dohar, M.; Watanabe, K. Advantages of unmanned aerial vehicle (UAV) photogrammetry for landscape analysis compared with satellite data: A case study of postmining sites in Indonesia. Cogent Geosci. 2018, 4, 1498180. [CrossRef]

134. Tomczyk, A.M.; Ewertowski, M.W.; Stawska, M.; Rachlewicz, G. Detailed alluvial fan geomorphology in a high-arctic periglacial environment, Svalbard: Application of unmanned aerial vehicle (UAV) surveys. J. Maps 2019, 15, 460-473. [CrossRef]

135. Tomczyk, A.M.; Ewertowski, M.W. UAV-based remote sensing of immediate changes in geomorphology following a glacial lake outburst flood at the Zackenberg river, northeast Greenland. J. Maps 2020, 16, 86-100. [CrossRef]

136. Wang, T.; Çelik, K.; Somani, A.K. Meta-image navigation augmenters for GPS denied mountain navigation of small UAS. In Proceedings of the Airborne Intelligence, Surveillance, Reconnaissance (ISR) Systems and Applications, Baltimore, MD, USA, 9 June 2014; p. 907604. [CrossRef]

137. Chesley, J.T.; Leier, A.L.; White, S.; Torres, R. Using unmanned aerial vehicles and structure-from-motion photogrammetry to characterize sedimentary outcrops: An example from the Morrison Formation, Utah, USA. Sediment. Geol. 2017, 354, 1-8. [CrossRef]

138. Oliveira, S.; Moura, D.; Boski, T.; Horta, J. Coastal paleokarst landforms: A morphometric approach via UAV for coastal management (Algarve, Portugal case study). Ocean Coast. Manag. 2019, 167, 245-261. [CrossRef]

139. Belley, P.M.; Shang, P.; Lake, D.J. Gem Exploration Using a Camera Drone and Geospatial Analysis: A Case Study of Peridot Exploration in British Columbia, Canada. J. Gemmol. 2020, 37, 80-90. [CrossRef]

140. De Donatis, M.; Alberti, M.; Cipicchia, M.; Guerrero, N.M.; Pappafico, G.F.; Susini, S. Workflow of Digital Field Mapping and Drone-Aided Survey for the Identification and Characterization of Capable Faults: The Case of a Normal Fault System in the Monte Nerone Area (Northern Apennines, Italy). ISPRS Int. J. Geo-Inf. 2020, 9, 616. [CrossRef] 
141. Piégay, H.; Arnaud, F.; Belletti, B.; Bertrand, M.; Bizzi, S.; Carbonneau, P.; Dufour, S.; Liebault, F.; Ruiz-Villanueva, V.; Slater, L. Remotely Sensed Rivers in the Anthropocene: State of the Art and Prospects. Earth Surf. Process. Landf. 2020, 45, 157-188. [CrossRef]

142. Specht, C.; Lewicka, O.; Specht, M.; Dabrowski, P.; Burdziakowski, P. Methodology for Carrying out Measurements of the Tombolo Geomorphic Landform Using Unmanned Aerial and Surface Vehicles near Sopot Pier, Poland. J. Mar. Sci. Eng. 2020, 8, 384. [CrossRef]

143. Albarelli, D.S.N.A.; Mavrouli, O.C.; Nyktas, P. Identification of potential rockfall sources using UAV-derived point cloud. Bull. Eng. Geol. Environ. 2021, 80, 6539-6561. [CrossRef]

144. Rechberger, C.; Fey, C.; Zangerl, C. Structural characterisation, internal deformation, and kinematics of an active deep-seated rockslide in a valley glacier retreat area. Eng. Geol. 2021, 286, 106048. [CrossRef]

145. Sales, J.C.; Bueno, G.T.; Rosolen, V.; Ferreira, M.E.; Furlan, L.M. The structure of an earth-mound field of the Brazilian Savanna. Geomorphology 2021, 386, 107752. [CrossRef]

146. Ewertowski, M.W.; Tomczyk, A.M.; Evans, D.J.A.; Roberts, D.H.; Ewertowski, W. Operational Framework for Rapid, Very-high Resolution Mapping of Glacial Geomorphology Using Low-cost Unmanned Aerial Vehicles and Structure-from-Motion Approach. Remote Sens. 2019, 11, 65. [CrossRef]

147. Ewertowski, M.W.; Tomczyk, A.M. Reactivation of temporarily stabilized ice-cored moraines in front of polythermal glaciers: Gravitational mass movements as the most important geomorphological agents for the redistribution of sediments (a case study from Ebbabreen and Ragnarbreen, Svalbard). Geomorphology 2020, 350, 106952. [CrossRef]

148. Nishar, A.; Richards, S.; Breen, D.; Robertson, J.; Breen, B. Thermal infrared imaging of geothermal environments and by an unmanned aerial vehicle (UAV): A case study of the Wairakei-Tauhara geothermal field, Taupo, New Zealand. Renew. Energy 2016, 86, 1256-1264. [CrossRef]

149. Smith, Z.D.; Maxwell, D.J. Constructing vertical measurement logs using UAV-based photogrammetry: Applications for multiscale high-resolution analysis of coarse-grained volcaniclastic stratigraphy. J. Volcanol. Geotherm. Res. 2021, 409, 107122. [CrossRef]

150. Hu, C.; Cheng, X.; Xiao, X.; Chen, Z.; Wang, Z.; Xu, J.; Zhao, D. Integrated application of water informatization: A case study from Zengcheng Guangzhou China. In Proceedings of the 2017 6th International Conference on Agro-Geoinformatics, Fairfax, VA, USA, 7-10 August 2017; pp. 1-5.

151. Wang, Y.; Xie, H. A Review on Applications of Remote Sensing and Geographic Information Systems (GIS) in Water Resources and Flood Risk Management. Water 2018, 10, 608. [CrossRef]

152. Utlu, M.; Özdemir, H. How much spatial resolution do we need to model a local flood event? Benchmark testing based on UAV data from Biga River (Turkey). Arab. J. Geosci. 2020, 13, 1293. [CrossRef]

153. Psomiadis, E.; Tomanis, L.; Kavvadias, A.; Soulis, K.X.; Charizopoulos, N.; Michas, S. Potential Dam Breach Analysis and Flood Wave Risk Assessment Using HEC-RAS and Remote Sensing Data: A Multicriteria Approach. Water 2021, 13, 364. [CrossRef]

154. Sarira, T.V.; Clarke, K.; Weinstein, P.; Koh, L.P.; Lewis, M. Rapid identification of shallow inundation for mosquito disease mitigation using drone-derived multispectral imagery. Geospat. Health 2020, 15. [CrossRef] [PubMed]

155. Erena, M.; Atenza, J.F.; García-Galiano, S.; Domínguez, J.A.; Bernabé, J.M. Use of Drones for the Topo-Bathymetric Monitoring of the Reservoirs of the Segura River Basin. Water 2019, 11, 445. [CrossRef]

156. Kuntz Rangel, R.; Freitas, J.L.; Rodrigues, A.V. Development of a Multipurpose Hydro Environmental Tool using Swarms, UAV and USV. In Proceedings of the 2019 IEEE Aerospace Conference, Big Sky, MT, USA, 2-9 March 2019; pp. 1-15. [CrossRef]

157. Lambev, T.; Prodanov, B.; Dimitrov, L.; Kotsev, I. Digital bathymetric model of the Burgas Bay, Bulgarian Black Sea. In Proceedings of the Eighth International Conference on Remote Sensing and Geoinformation of the Environment, Paphos, Cyprus, 16-18 March 2020; p. 1152421. [CrossRef]

158. Feagin, R.A.; Johns, N.; Huff, T.P.; Abdullah, M.M.; Fritz-Grammond, K. Restoration of Freshwater Inflows: The Use of Spatial Analysis for Hydrologic Planning in the Anahuac National Wildlife Refuge, USA. Wetlands 2020, 40, 2561-2576. [CrossRef]

159. Papakonstantinou, A.; Topouzelis, K.; Doukari, M. UAS close range remote sensing for mapping coastal environments. In Proceedings of the Fifth International Conference on Remote Sensing and Geoinformation of the Environment (RSCy2017), Paphos, Cyprus, 6 September 2017; p. 1044418. [CrossRef]

160. Gonçalves, G.; Santos, S.; Duarte, D.; Gomes, J. Monitoring Local Shoreline Changes by Integrating UASs, Airborne LiDAR, Historical Images and Orthophotos. In Proceedings of the 5th International Conference on Geographical Information Systems Theory, Applications and Management-GISTAM, Heraklion, Crete, Greece, 3-5 May 2019; pp. 126-134. [CrossRef]

161. Themistocleous, K.; Mettas, C.; Evagorou, E.; Hadjimitsis, D. The use of satellite remote sensing and UAV for the mapping of coastal areas for the use of marine spatial planning. In Proceedings of the Earth Resources and Environmental Remote Sensing/GIS Applications X, Strasbourg, France; 2019; p. 1115610. [CrossRef]

162. Evelpidou, N.; Zerefos, C.; Synolakis, C.; Repapis, C.; Karkani, A.; Polidorou, M.; Saitis, G. Coastal Boulders on the SE Coasts of Cyprus as Evidence of Palaeo-Tsunami Events. J. Mar. Sci. Eng. 2020, 8, 812. [CrossRef]

163. Green, D.R. Coastal and marine studies in the department of geography and environment at the University of Aberdeen. Scott. Geogr. J. 2019, 135, 257-266. [CrossRef]

164. Gómez-Pazo, A.; Pérez-Alberti, A. The Use of UAVs for the Characterization and Analysis of Rocky Coasts. Drones 2021, 5, 23. [CrossRef] 
165. Shenbagaraj, N.; Senthil Kumar, K.; Rasheed, A.M.; Leostalin, J.; Kumar, M. Mapping and Electronic Publishing of Shoreline Changes using UAV Remote Sensing and GIS. J. Indian Soc. Remote Sens. 2021, 49, 1769-1777. [CrossRef]

166. Li, Z.; Mu, S.; Li, J.; Wang, W.; Liu, Y. Transmission line intelligent inspection central control and mass data processing system and application based on UAV. In Proceedings of the 2016 4th International Conference on Applied Robotics for the Power Industry (CARPI), Jinan, China, 11-13 October 2016; pp. 1-5. [CrossRef]

167. Weglicki, R.; Kowalczyk, K.; Ogórek, T. The integration of numerical and raster data for engineering tasks. In Proceedings of the Geographic Information Systems Conference and Exhibition "GIS ODYSSEY 2017", Trento-Vattaro, Italy, 4-8 September 2017.

168. Pylarinos, D. Overhead Transmission Line Maintenance in Crete and Rhodes: 2016-2020. Eng. Technol. Appl. Sci. Res. 2021, 11, 6833-6844. [CrossRef]

169. Zhang, Y.; Ren, Z.; Liu, L.; Wei, C.; Yin, C. Design for a fast high precision UAV power emergency relief system. In Proceedings of the 2016 4th International Conference on Applied Robotics for the Power Industry (CARPI), Jinan, China, 11-13 October 2016; pp. 1-4. [CrossRef]

170. Angeli, S.; Lingua, A.M.; Maschio, P.; Piantelli, L.; Dugone, D.; Giorgis, M. Dense 3D Model Generation of a Dam Surface Using UAV for Visual Inspection. In Advances in Service and Industrial Robotics. RAAD 2018. Mechanisms and Machine Science; Aspragathos, N., Koustoumpardis, P., Moulianitis, V., Eds.; Springer: Cham, Switzerland, 2019; Volume 67. [CrossRef]

171. Mavroulis, S.; Andreadakis, E.; Spyrou, N.I.; Antoniou, V.; Skourtsos, E.; Papadimitriou, P.; Kasssaras, I.; Kaviris, G.; Tselentis, G.A.; Voulgaris, N.; et al. UAV and GIS based rapid earthquake-induced building damage assessment and methodology for EMS-98 isoseismal map drawing: The June 12, 2017 Mw 6.3 Lesvos (Northeastern Aegean, Greece) earthquake. Int. J. Disaster Risk Reduct. 2019, 37, 101169. [CrossRef]

172. Xiong, C.; Li, Q.; Lu, X. Automated regional seismic damage assessment of buildings using an unmanned aerial vehicle and a convolutional neural network. Autom. Constr. 2020, 109, 102994. [CrossRef]

173. Kovacevic, M.S.; Gavin, K.; Stipanovic Oslakovic, I.; Bacic, M. A New Methodology for Assessment of Railway Infrastructure Condition. Transp. Res. Procedia 2016, 14, 1930-1939. [CrossRef]

174. Kejuruteraan, J.; Mauluda, K.N.; Jaafara, O. Auditing Road Maintenance Work Using Unmanned Aerial Vehicle. J. Kejuruter. SI 2019, 1, 23-27. [CrossRef]

175. Gajjar, Y. Monitoring of Pipeline RoU Using Remote Sensing and GIS Techniques. In Proceedings of the ASME 2017 India Oil and Gas Pipeline Conference, Mumbai, India, 20-22 April 2017. [CrossRef]

176. Usta, Z.; Cömert, Ç.; Yilmaz, V. Solar Energy Potential of Cities in Turkey; A GIS Based Analysis. Fresenius Environ. Bull. 2017, 26, 80-83.

177. Fuentes, J.E.; Moya, F.D.; Montoya, O.D. Method for Estimating Solar Energy Potential Based on Photogrammetry from Unmanned Aerial Vehicles. Electronics 2020, 9, 2144. [CrossRef]

178. Patrikar, J.; Moon, B.; Scherer, S. Wind and the City: Utilizing UAV-Based In-Situ Measurements for Estimating Urban Wind Fields. In Proceedings of the (IROS) IEEE/RSJ International Conference on Intelligent Robots and Systems, Las Vegas, NV, USA, 24 October 2020-24 January 2021; pp. 1254-1260.

179. Filipova, S.; Filipov, D.; Raeva, P. Creating 3D model of an open pit quarry by uav imaging and analysis in GIS. In Proceedings of the 6th International Conference on Cartography and GIS, Albena, Bulgaria, 13-17 June 2016; Bandrova, T., Konecny, M., Eds.; ISSN: 1314-0604.

180. Carabassa, C.; Montero, P.; Crespo, M.; Padró, J.C.; Pons, X.; Balagué, J.; Brotons, L.; Alcañiz, J.M. Unmanned aerial system protocol for quarry restoration and mineral extraction monitoring. J. Environ. Manag. 2020, 270, 110717. [CrossRef] [PubMed]

181. Rokhmana, C.A.; Utomo, S. The Low-Cost UAV-Based Remote Sensing System Capabilities for Large Scale Cadaster Mapping. In Proceedings of the IOP Conference Series: Earth and Environmental Science, Volume 47, 2nd International Conference of Indonesian Society for Remote Sensing (ICOIRS), Yogyakarta, Indonesia, 17-19 October 2016.

182. Khadanga, G.; Jain, K. Cadastral Parcel Boundary Extraction from UAV Images. J. Indian Soc. Remote Sens. 2021, 49, 593-599. [CrossRef]

183. Schierbeck, S.; Nord, A.; Svensson, L.; Rawshani, A.; Hollenberg, J.; Ringh, M.; Forsberg, S.; Nordberg, P.; Hilding, F.; Claesson, A National coverage of out-of-hospital cardiac arrests using automated external defibrillator-equipped drones-A geographical information system analysis. Resuscitation 2021, 163, 136-145. [CrossRef] [PubMed]

184. Claesson, A.; Fredman, D.; Svensson, L.; Ringh, M.; Hollenberg, J.; Nordberg, P.; Rosenqvist, M.; Djarv, T.; Österberg, S.; Lennartsson, J.; et al. Unmanned aerial vehicles (drones) in out-of-hospital-cardiac-arrest. Scand. J. Trauma Resusc. Emerg. Med. 2016, 24, 124. [CrossRef] [PubMed]

185. Pulver, A.; Wei, R.; Mann, C. Locating AED Enabled Medical Drones to Enhance Cardiac Arrest Response Times. Prehospital Emerg. Care 2016, 20, 378-389. [CrossRef]

186. Pulver, A.; Wei, R. Optimizing the spatial location of medical drones. Appl. Geogr. 2018, 90, 9-16. [CrossRef]

187. Kabiri, K. Mapping coastal ecosystems and features using a low-cost standard drone: Case study, Nayband Bay, Persian gulf, Iran. J. Coast Conserv. 2020, 24, 62. [CrossRef]

188. Kotsev, I.S.; Prodanov, B.K.; Bekova, R.I.; Lambev, T.H. UAS-based mapping of depositional landforms along the North Bulgarian Black Sea coast in support of nature conservation. In Proceedings of the Eighth International Conference on Remote Sensing and Geoinformation of the Environment (RSCy2020), Paphos, Cyprus, 26 August 2020; p. 1152426. [CrossRef] 
189. Strumia, S.; Buonanno, M.; Aronne, G.; Santo, A.; Santangelo, A. Monitoring of Plant Species and Communities on Coastal Cliffs: Is the Use of Unmanned Aerial Vehicles Suitable? Diversity 2020, 12, 149. [CrossRef]

190. Chabot, D.; Dillon, C.; Shemrock, A.; Weissflog, N. Sager EPS. An Object-Based Image Analysis Workflow for Monitoring Shallow-Water Aquatic Vegetation in Multispectral Drone Imagery. ISPRS Int. J. Geo-Inf. 2018, 7, 294. [CrossRef]

191. Kentsch, S.; Cabezas, M.; Tomhave, L.; Groß, J.; Burkhard, B.; Lopez Caceres, M.L.; Waki, K.; Diez, Y. Analysis of UAV-Acquired Wetland Orthomosaics Using GIS, Computer Vision, Computational Topology and Deep Learning. Sensors 2021, $21,471$. [CrossRef] [PubMed]

192. Jiang, W.; Liu, L.; Xiao, H.; Zhu, S.; Li, W.; Liu, Y. Composition and distribution of vegetation in the water level fluctuating zone of the Lantsang cascade reservoir system using UAV multispectral imagery. PLoS ONE 2021, 16, e0247682. [CrossRef]

193. Caprioli, M.; Trizzino, R.; Mazzone, F.; Scarano, M. Experiences of UAV surveys applied to environmental risk management. Int. Arch. Photogramm. Remote Sens. Spatial Inf. Sci. 2016, XLI-B1, 797-801. [CrossRef]

194. Daugela, I.; Visockiene, J.S.; Aksamitauskas, V.C. RPAS and GIS for landfill analysis. In Proceedings of the 10th Conference on Interdisciplinary Problems in Environmental Protection and Engineering EKO-DOK, Polanica-Zdroj, Poland, 16-18 April 2018; p. 44. [CrossRef]

195. Reaney, S.M.; Mackaym, E.B.; Haygarth, P.M.; Fisher, M.; Molineux, A.; Potts, M.; Benskin, C.M. Identifying critical source areas using multiple methods for effective diffuse pollution mitigation. J. Environ. Manag. 2019, 250, 109366. [CrossRef] [PubMed]

196. Sheng, Q.; Zhang, Y.; Zhu, Z.; Li, W.; Xu, J.; Tang, R. An experimental study to quantify road greenbelts and their association with $\mathrm{PM}_{2.5}$ concentration along city main roads in Nanjing, China. Sci. Total. Environ. 2019, 667, 710-717. [CrossRef]

197. Romano, F.; Marucci, A.; Fiorini, L.; Ciabo, S.; Romano, B. New techniques for land surveying, monitoring and environmental diagnosis: A comparative analysis. In Proceedings of the XIV International Forum World Heritage and Degradation, Napoli, Italy, 16-18 June 2016.

198. Su, T.C. Environmental risk mapping of physical cultural heritage using an unmanned aerial remote sensing system: A case study of the Huang-Wei monument in Kinmen, Taiwan. J. Cult. Herit. 2019, 39, 140-151. [CrossRef]

199. Escobar-Sánchez, G.; Haseler, M.; Oppelt, N.; Schernewski, G. Efficiency of Aerial Drones for Macrolitter Monitoring on Baltic Sea Beaches. Front. Environ. Sci. 2021, 8, 560237. [CrossRef]

200. Fys, M.; Yurkiv, M.; Lozynskyi, V. Modeling of 3-D objects using geodetic and cartographic data and determining their volumes with an accuracy assessment. Remote Sens. Appl. Soc. Environ. 2021, 22, 100506. [CrossRef]

201. Wolf, N.; Siegmund, A.; del Río, C.; Osses, P.; García, J.L. Remote sensing-based detection and spatial pattern analysis for geo-ecological niche modeling of Tillandsia spp. in the Atacama, Chile. Int. Arch. Photogramm. Remote Sens. Spat. Inf. Sci. 2016, XLI-B2, 251-256. [CrossRef]

202. Guo, Q.; Su, Y.; Hu, T.; Zhao, X.; Wu, F.; Li, Y.; Liu, J.; Chen, L.; Xu, G.; Lin, G.; et al. An integrated UAV-borne lidar system for 3D habitat mapping in three forest ecosystems across China. Int. J. Remote Sens. 2017, 38, 2954-2972. [CrossRef]

203. Li, L.; Tietze, D.T.; Fritz, A.; Lü, Z.; Bürgi, M.; Storch, I. Rewilding cultural landscape potentially puts both avian diversity and endemism at risk: A Tibetan Plateau case study. Biol. Conserv. 2018, 224, 75-86. [CrossRef]

204. Plaščak, I.; Jurišić, M.; Šiljeg, A.; Jeftić, L.; Zimmer, D.; Barač, Ž. Remote detection of ragweed (Ambrosia artemisiifolia L.). Teh. Glas.-Tech. J. 2018, 12, 226-230. [CrossRef]

205. Schaub, J.; Hunt, B.P.V.; Pakhomov, E.A.; Holmes, K.; Lu, Y.; Quayle, L. Using unmanned aerial vehicles (UAVs) to measure jellyfish aggregations. Mar. Ecol. Prog. Ser. 2018, 591, 29-36. [CrossRef]

206. Xavier, S.S.; Coffin, A.W.; Olson, D.M.; Schmidt, J.M. Remotely Estimating Beneficial Arthropod Populations: Implications of a Low-Cost Small Unmanned Aerial System. Remote Sens. 2018, 10, 1485. [CrossRef]

207. Fadeev, N.B.; Skrypitsyna, T.N.; Kurkov, V.M.; Sidelnikov, N.I. Use of Remote Sensing Data and GIS Technologies for Monitoring Stocks of Medicinal Plants: Problems and Prospects. In Information Technologies in the Research of Biodiversity; Springer Proceedings in Earth and Environmental Sciences; Bychkov, I., Voronin, V., Eds.; Springer: Cham, Switzerland, 2019. [CrossRef]

208. Woellner, R.; Wagner, T.C. Saving species, time and money: Application of unmanned aerial vehicles (UAVs) for monitoring of an endangered alpine river specialist in a small nature reserve. Biol. Conserv. 2019, 233, 162-175. [CrossRef]

209. Francis, R.J.; Lyons, M.B.; Kingsford, R.T.; Brandis, K.J. Counting Mixed Breeding Aggregations of Animal Species Using Drones: Lessons from Waterbirds on Semi-Automation. Remote Sens. 2020, 12, 1185. [CrossRef]

210. Ha, S.; Yang, Z. Suitability Assessment of the Tools Under a Three-Dimension System of Landscape Monitoring: A Case Study in the NWHS of Bogda. Sustainability 2020, 12, 649. [CrossRef]

211. Lashchinskiy, N.N.; Kartoziia, A.A.; Faguet, A.N. Permafrost Degradation as a Supporting Factor for the Biodiversity of Tundra Ecosystems. Contemp. Probl. Ecol. 2020, 13, 401-411. [CrossRef]

212. Linol, B.; Miller, W.; Rensburg, C.; Schoeman, R.; Bezuidenhout, L.; Genin, F.; Morkel, B.; Dhliwayo, N.; Jeppesen, K.; Dlakavu, S.; et al. Earth Stewardship Science-Transdisciplinary Contributions to Quantifying Natural and Cultural Heritage of Southernmost Africa. Remote Sens. 2020, 12, 420. [CrossRef]

213. Song, B.; Park, K. Detection of Aquatic Plants Using Multispectral UAV Imagery and Vegetation Index. Remote Sens. 2020, $12,387$. [CrossRef]

214. Korne, N.; Flemming, S.; Smith, P.; Nol, E. Applying structure-from-motion habitat reconstruction and GIS terrain analysis to test hypotheses about nest-site selection by shorebirds. J. Field Ornithol. 2020, 91, 421-432. [CrossRef] 
215. Al-Emadi, S.; Al-Ali, A.; Al-Ali, A. Audio-Based Drone Detection and Identification Using Deep Learning Techniques with Dataset Enhancement through Generative Adversarial Networks. Sensors 2021, 21, 4953. [CrossRef]

216. Ivoševic, J.; Gani, E.; Petoši, A.; Radiši, T. Comparative UAV Noise-Impact Assessments through Survey and Noise Measurements. Int. J. Environ. Res. Public Health 2021, 18, 6202. [CrossRef]

217. Skorput, P.; Mandzuka, S.; Vojvodic, H. The use of Unmanned Aerial Vehicles for forest fire monitoring. In Proceedings of the 2016 International Symposium ELMAR, Zadar, Croatia, 12-14 September 2016; pp. 93-96. [CrossRef]

218. Valero, M.M.; Rios, O.; Mata, C.; Pastor, E.; Planas, E. An integrated approach for tactical monitoring and data-driven spread forecasting of wildfires. Fire Saf. J. 2017, 91, 835-844. [CrossRef]

219. Sofan, P.; Bruce, D.; Jones, E.; Marsden, J. Detection and Validation of Tropical Peatland Flaming and Smouldering Using Landsat-8 SWIR and TIRS Bands. Remote Sens. 2019, 11, 465. [CrossRef]

220. Miquel, T.; Sorin, J.L.; Maurin, J.; Tourment, R.; Pons, F.; Bohard, J.; Biscay, J.F. DIDRO Project-New means for surveying dikes and similar flood defense structures. In Proceedings of the 3rd European Conference on Flood Risk Management FLOODrisk, Lyon, France, 17-21 October 2016.

221. Șerban, G.; Rus, I.; Vele, D.; Breţcan, P.; Alexe, M.; Petrea, D. Flood-prone area delimitation using UAV technology, in the areas hard-to-reach for classic aircrafts: Case study in the north-east of Apuseni Mountains, Transylvania. Nat. Hazards 2016, 82, 1817-1832. [CrossRef]

222. Ajmar, A.; Boccardo, P.; Broglia, M.; Kucera, J.; Giulio-Tonolo, F.; Wania, A. Response to flood events: The role of satellite-based emergency mapping and the experience of the Copernicus Emergency Management Service. Flood Damage Surv. Assess. New Insights Res. Pract. 2017, 228, 213-228.

223. Lin, S.W.; Yen, C.F.; Chang, C.H.; Wang, L.J.; Shih, H.J. Comprehensive Natural Environment and Landscape Signs in Coastal Settlement Hazard Assessment: Case of East Taiwan between the Coastal Mountain and the Pacific Ocean. J. Mar. Sci. Eng. 2020, 8, 478. [CrossRef]

224. Wang, N. "We Live on Hope ... ": Ethical Considerations of Humanitarian Use of Drones in Post-Disaster Nepal. IEEE Technol. Soc. Mag. 2020, 39, 76-85. [CrossRef]

225. Whitehurst, D.; Friedman, B.; Kochersberger, K.; Sridhar, V.; Weeks, J. Drone-Based Community Assessment, Planning, and Disaster Risk Management for Sustainable Development. Remote Sens. 2021, 13, 1739. [CrossRef]

226. Oliveira Silva, L.; de Mello Bandeira, R.A.; Barcellos Gouvêa Campos, V. Proposal to planning facility location using UAV and geographic information systems in a post-disaster scenario. Int. J. Disaster Risk Reduct. 2019, 36, 101080. [CrossRef]

227. Kamnik, R.; Perc, M.N.; Topolšek, D. Using the scanners and drone for comparison of point cloud accuracy at traffic accident analysis. Accid. Anal. Prev. 2020, 135, 105391. [CrossRef]

228. Park, G.; Lee, B.; Kim, D.G.; Lee, Y.J.; Sung, S. Design and Performance Validation of Integrated Navigation System Based on Geometric Range Measurements and GIS Map for Urban Aerial Navigation. Int. J. Control Autom. Syst. 2020, 18, $2509-2521$. [CrossRef]

229. Nguyen, D.D.; Rohacs, J.; Rohacs, D. Autonomous Flight Trajectory Control System for Drones in Smart City Traffic Management. ISPRS Int. J. Geo-Inf. 2021, 10, 338. [CrossRef]

230. He, Y.; Ma, W.; Ma, Z.; Fu, W.; Chen, C.; Yang, C.F.; Liu, Z. Using Unmanned Aerial Vehicle Remote Sensing and a Monitoring Information System to Enhance the Management of Unauthorized Structures. Appl. Sci. 2019, 9, 4954. [CrossRef]

231. Antoniou, V.; Nomikou, P.; Bardouli, P.; Lampridou, D.; Ioannou, T.; Kalisperakis, I.; Stentoumis, C.; Whitworth, M.; Krokos, M.; Ragia, L. An Interactive Story Map for the Methana Volcanic Peninsula. In GISTAM; Funchal: Madeira, Portugal, 2018.

232. Lee, S.Y.; Du, C.; Chen, Z.; Wu, H.; Guan, K.; Liu, Y.; Cui, Y.; Li, W.; Fan, Q.; Liao, W. Assessing Safety and Suitability of Old Trails for Hiking Using Ground and Drone Surveys. ISPRS Int. J. Geo-Inf. 2020, 9, 221. [CrossRef]

233. Bonatti, R.; Wang, W.; Ho, C.; Ahuja, A.; Gschwindt, M.; Camci, E.; Kayacan, E.; Choudhury, S.; Scherer, S. Autonomous aerial cinematography in unstructured environments with learned artistic decision-making. J. Field Robot. 2020, 37, 606-641. [CrossRef]

234. Spano, A.; Chiabrando, F.; Dezzani, L.; Prencipe, A. Digital Segusio: From models generation to urban reconstruction. Virtual Archaeol. Rev. 2016, 7, 87-97. [CrossRef]

235. Adão, T.; Padua, L.; Hruska, J.; Sousa, J.J.; Morais, R.; Magalhaes, L.G. Bringing together UAS-based land surveying and procedural modelling of buildings to set up enhanced VR environments for cultural heritage. In Proceedings of the $201724^{\circ}$ Encontro Português de Computação Gráfica e Interação (EPCGI), Guimaraes, Portugal, 12-13 October 2017; pp. 1-8. [CrossRef]

236. Colombatti, G.; Aboudan, A.; Bettanini, C.; Magnini, L.; Bettineschi, C.; Deotto, G.; Toninello, L.; Debei, S.; De Guio, A.; Zanovello, P.; et al. Horus-A drone project for visual and IR imaging. In Proceedings of the 2017 IEEE International Workshop on Metrology for AeroSpace, Padua, Italy, 21-23 June 2017. [CrossRef]

237. Decker, M.J.; Du Vernay, J.P.; McLeod, J.B. Putting roman dams in context: A virtual approach. In Proceedings of the The International Archives of the Photogrammetry, Remote Sensing and Spatial Information Sciences, Volume XLII-2/W5, 2017, 26th International CIPA Symposium 2017, Ottawa, ON, Canada, 28 August-1 September 2017.

238. Castagno, J.; Atkins, E. Roof Shape Classification from LiDAR and Satellite Image Data Fusion Using Supervised Learning. Sensors 2018, 18, 3960. [CrossRef]

239. Zheng, X.; Wang, F.; Li, Z. A multi-UAV cooperative route planning methodology for 3D fine-resolution building model reconstruction. Netherlands: N. ISPRS J. Photogramm. Remote Sens. 2018, 146, 483-494. [CrossRef] 
240. Li, D.; Lu, M. Integrating geometric models, site images and GIS based on Google Earth and Keyhole Markup Language. Autom. Constr. 2018, 89, 317-331. [CrossRef]

241. Afnarius, S.; Syukur, M.; Ekaputra, E.G.; Parawita, Y.; Darman, R. Development of GIS for Buildings in the Customary Village of Minangkabau Koto Gadang, West Sumatra, Indonesia. ISPRS Int. J. Geo-Inf. 2020, 9, 365. [CrossRef]

242. Budiharto, W.; Irwansyah, E.; Suroso, J.S.; Chowanda, A.; Ngarianto, E.; Santoso Gunawan, A.A. Mapping and 3D modelling using quadrotor drone and GIS software. J. Big Data 2021, 8, 48. [CrossRef]

243. Harrington, M.C.R.; Bledsoe, Z.; Jones, C.; Miller, J.; Pring, T. Designing a Virtual Arboretum as an Immersive, Multimodal, Interactive, Data Visualization Virtual Field Trip. Multimodal Technol. Interact. 2021, 5, 18. [CrossRef]

244. Acemoglu, D.; Robinson, J. Why Nations Fail: The Origins of Power, Prosperity, and Poverty; Crown Business: New York, NY, USA, 2012. 